\title{
THE NATURE OF THE IRAN-UNITED STATES CLAIMS TRIBUNAL AND THE EVOLVING STRUGTURE OF INTERNATIONAL DISPUTE RESOLUTION
}

\author{
By David D. Caron*
}

The Iran-United States Claims Tribunal ${ }^{1}$ has been called "the most significant arbitral body in history"; 2 its awards, "a gold mine of information for perceptive lawyers." 3 In a recent international commercial arbitration, however, an arbitrator reportedly stated that decisions of the Tribunal, although on point, were not persuasive because the Tribunal, after all, involves a special type of arbitration. This arbitrator is not alone. A lecturer at the Hague Academy of International Law, speaking on international commercial arbitration, reportedly did not refer to the Tribunal's jurisprudence because he did not find it relevant to his work for the same reason. Viewed as a gigantic experiment in international dispute resolution rather than merely a claims settlement device for this particular group of disputes, the Tribunal thus appears (at least to some) to yield decisions of unclear precedential value. Millions of dollars have been spent on its operation and hundreds of awards rendered, yet an apparently not uncommon perception is that the work of this, in some respects unique, institution is not applicable elsewhere.

\footnotetext{
* Acting Professor of Law, University of California at Berkeley. Formerly Legal Assistant to Charles N. Brower and Richard M. Mosk, Members, Iran-United States Claims Tribunal. The author wishes to thank George H. Aldrich, Charles N. Brower, Richard M. Buxbaum, John R. Crook, David Feller, Richard M. Mosk, Stefan A. Riesenfeld, Stephen M. Schwebel, Peter D. Trooboff, Albert Jan van den Berg, Jan Vetter and Joachim Zekoll for their comments. He also thanks Joseph Giansiracusa, J.D. Boalt Hall, '89, for his able research assistance.

' The Iran-United States Claims Tribunal was established in 1981 pursuant to the Declaration of the Government of the Democratic and Popular Republic of Algeria (hereinafter General Declaration) and the Declaration of the Government of the Democratic and Popular Republic of Algeria concerning the Settlement of Claims by the Government of the United States of America and the Government of the Islamic Republic of Iran (hereinafter Claims Settlement Declaration), collectively referred to as the Algiers Accords. For the text of the Accords, see 1 Iran-United States Claims Tribunal Reports [hereinafter IRAN-U.S. C.T.R.] 3 (1981-2), 75 AJIL 418 (1981). As to citation of awards by the Tribunal, see note 123 infra.

As to the Tribunal, see generally Brower \& Davis, The Iran-United States Claims Tribunal After Seven Years: A Retrospective View from the Inside, 43 ARB. J. 16 (1988); THE IRAN-UNITED STATES Claims Tribunal 1981-1983 (R. Lillich ed. 1984) [hereinafter IRAN-UNITED STAtes Tribunal]; Stewart, The Iran-United States Clains Tribunal: A Review of Developments 1983-84, 16 L. \& POL'Y INT'L Bus. 677 (1984); and Selby \& Stewart, Practical Aspects of Arbitrating Claims Before the Iran-United States Claims Tribunal, 18 INT'L LAw. 211 (1984).

${ }^{2}$ Lillich, Preface to THE IRAN-UNITEd STATES Claims TRIBUNAL, supra note 1 , at vii.

${ }^{3}$ Holtzmann, Some Lessons of the Iran-United States Claims Tribunal, in 1988 Private INVES. TORS ABROAD-PROBLEMS AND SOLUTIONS IN INTERNATIONAL BUSINESS 16-5 (J. Moss ed.). Indeed, decisions of the Tribunal are cited in a number of Reporters' Notes to the Restatement (Third) of the Foreign Relations Law of the United States (1987).
} 
In one sense, the doubt about the relevance of the Tribunal's work reflects a more fundamental uncertainty about the proper place of the Tribunal and its work within traditional categories of international dispute resolution. ${ }^{*}$ Like any truly nagging question, that fundamental uncertainty comes to be phrased in various ways. A phrasing frequently used by scholars inquires into the "nature" of the Tribunal. ${ }^{5}$ The assumption apparently underlying this question is that there are basically two distinct types of international arbitration: ${ }^{6}$ interstate arbitration such as the Beagle Channel

A complete discussion of the precedential value that should be given the work of the Tribunal would have several dimensions. The Tribunal's work is potentially significant for various reasons: it is the first major claims tribunal since the interwar period; its orders, awards and much of its workings are open to public (hence scholarly) examination; its docket of approximately 3,850 cases involves issues such as exchange-control regulation, expropriation and expulsion; and it is conducting its work in general in accordance with the UNCITRAL Arbitration Rules (ste infra notes 26 and 110). This potential significance has been challenged on the ground that combative arbitrators have politicized both the procedural and the substantive decisions of the Tribunal. See also M. Sornarajah, The Pursuit of Nationalized Property 202 (1986) ("the jurisprudential value of the awards . . . [is] open to doubt on the ground that they were based on an agreement settling a political dispute and that there was an effort made by the Tribunal to approach issues in a manner favouring compromise"). The significance has also been challenged on the ground that the third-country chairmen have all been drawn from Western countries and thus bring with them the jurisprudential predispositions of their cultures. Both of these challenges are beyond the scope of this article and deserve a separate, extended response. To state my views briefly, however, I do not believe either objection stands up to scrutiny or is substantial. As to the former, I believe the combativeness of the Iranian arbitrators did not politicize substantive decisions, although it is true that, procedurally, extensions of time were more frequently granted to the Iranian parties than many U.S. claimants would have desired. The ingenuity of the Iranians, if anything, only tested and pushed at every aspect of the UNCITRAL Rules. The Tribunal met such tests and, in my opinion, has shown the workability and value of the Rules. On the Tribunal's work in one area of arbitral procedure, see Caron, Interim Measures of Protection: Theory and Practice in Light of the Irtu-L'ntted States Claims Tribunal, 46 ZEITSCHRIFT Für AUSLÄNDISCHES ÖFFENTLICHES RECHT UND VÖLKERRECHT 465 (1986).

As to the latter objection, the third-country arbitrators have come from Western countries (two Swedes, two Frenchmen, one Swiss, one Dutchman, one German, one Italian and one Finn), but Iran (or arbitrators appointed by Iran) agreed to the selection of seven of the nine. More importantly, the charge of Western bias is directed really at only one, albeit emotional, issue-expropriation. Even then, the issue in controversy is not what constitutes a taking or whether compensation is due for a taking, but the appropriate standard for determining the amount of compensation.

As the precedential value of an international decision should turn upon its persuasiveness to the next panel, the challenge posed by the uncertainty about the nature of the Tribunal is subtle and indirect. I would speculate that the reluctance of some private international arbitrators to rely on the Tribunal's decisions reflects their intuitive conclusion that the Tribunal involves the classic interstate arbitral process and the further intuitive conclusion that the process is therefore particularly politicized. In this sense, a complete discussion of the precedential value of Tribunal awards will require further examination of the challenges to the integrity of the process described above.

${ }^{5} S_{i t}$, e.g., Decasions of the Iran-United States Claims Tribunal, Remarks of David Lloyd Jones, 78 ASIL Proc. 225, 226 (1984).

"During the preparation of this study, I generally found the distinction between public and private international arbitration to be held quite strongly, particularly among civil law scholars accustomed to a more systematic approach to law. Many scholars who stood by it were not altogether sure precisely what factors made an arbitration interstate rather than private, or 
arbitration between Chile and Argentina ${ }^{7}$ (sometimes referred to here as public international arbitration); and international commercial arbitration such as proceedings between private companies before the International Chamber of Commerce (ICC) (sometimes more broadly referred to here as private international arbitration). ${ }^{8}$ Practitioners often regard the inquiry into the nature of the process as irrelevant to lawyering until it is pointed out that many practical questions, such as the enforceability of an award and the ability to challenge an award, turn upon the answer.

As discussed more fully below, a simple inquiry into the legal "nature" of an international arbitral process is too undefined because any one of several aspects could be emphasized. This article in particular examines the relationship of the international legal system and the various municipal legal systems to the arbitrations before the Tribunal, and, in doing so, discusses more broadly the evolving structure of international dispute resolution. I am not concerned here with what law the arbitrators might apply within the Tribunal, but rather with the positions that will be taken under various legal systems on the validity and enforceability of the Tribunal's arbitral awards.

Since practical consequences such as enforceability and recognition can turn upon the nature of an arbitration, it may not be surprising that the Islamic Republic of Iran and the United States have disagreed over which legal system governs the validity of arbitrations before the Tribunal. Indeed, they have disagreed even as to who the parties are for many of the arbitrations. ${ }^{9}$ But it is not only the two state parties that have expressed differing views. Advocates as well as scholars have taken a variety of positions on the characterization issue. The Dutch Government proposed legislation in 1984 that would provide clearly for the Dutch legal system to review the validity of the arbitral process. ${ }^{10}$ Yet a British judge has stated that "the Dutch Courts would probably . . . wholly decline to recognize the validity in Dutch law of [such] arbitration proceedings" and would therefore declare such proceedings a "nullity." Meanwhile, the United States Court of Appeals for the Ninth Circuit recently affirmed a district court ruling that the New York Convention on the Recognition and Enforcement

what insights were gained by the distinction. For many, their intuitive judgment was that arbitrations before the Tribunal have an interstate nature. Another response, reflecting the difficulty of the question more than an answer, was to say that the arbitrations are of a "mixed" or "hybrid" nature.

7 Argentine-Chile Frontier Case, 16 R. Int'l Arb. Awards 109 (1966) (McNair, Kirwan \& Papworth arbs.).

${ }^{8}$ The term "private international arbitration" is used in this article to encompass international commercial arbitration, maritime arbitration and other similar manifestations of private arbitration. On the ICC, see W. GRaig, W. PARK \& J. PAulsSon, International Chamber of Commerce ARBitration (1983). See generally Stein \& Wotman, International Commercial Arbitration in the 1980s: A Comparison of the Major Arbitral Systems and Rules, 38 Bus. LAw. 1685 (1983).

${ }^{9}$ See infra text at notes 122-52. $\quad{ }^{10}$ See infra text at notes 178-86.

1 Mark Dallal v. Bank Mellat, [1986] 1 Q.B. 441, 2 W.L.R. 745, 1 All E.R. 239, noted in Fin. Times (London), Aug. 21, 1985, at 25, col. 1. See also Kunzlik, Public International Law-Cannot Govern a Contract, Can Authorise An Arbitration, 45 CAMBRIDGE L.J. 377 (1986). 
of Foreign Arbitral Awards "certainly is applicable" to awards rendered by the Tribunal. ${ }^{12}$ One Dutch commentator has concluded that its proceedings are not "arbitration" as understood under Dutch law, ${ }^{13}$ while another Dutchman has reached the opposite conclusion. ${ }^{14}$ Two American lawyers have together argued that the arbitrations are "a-national,"15 while another, the late Professor Ted Stein, stated that "[ $t]$ he lex fori of the Tribunal is public international law." "I6 Finally, Lady Hazel Fox recently wrote that the Tribunal is the latest example of how "a private party may . . . have its private claims taken up by the State and presented through an interstate arbitration." In short, virtually every possible position on the "nature" of the Tribunal's arbitrations has been put forward.

The analysis of the Tribunal's nature remains incomplete, not from a lack of attention or concern, but because the positions taken tend to rest on intuition supported only by analogies. For example, one position is that the Tribunal, like the International Court of Justice, was established by treaty and that the work of the Tribunal, like that of the Court, therefore has an interstate character. Moreover, the use of undefined terms such as "a-national," "denationalized" and "de-localized," and unclear distinctions such as that between interstate and international commercial arbitration, further confuse the discussion. Consequently, determining the significance of the Tribunal's work requires not only that we examine the Tribunal itself, but also that we understand the larger context and clarify what it means to distinguish between interstate and international commercial arbitration.

Part I introduces the international arbitral process and probes the weakness of the categorical distinction made between interstate and international commercial arbitration. I conclude that the issue is not whether an arbitration has this or that character, as if there existed distinct pigeonholes dictating such an approach. Rather, the proper inquiry should focus on what the parties intended the arbitration to be and what principles of construction should be applied in order to ascertain this intent.

${ }^{12}$ Ministry of Defense of Islamic Republic of Iran v. Gould, Inc., 887 F.2d 1357 (9th Cir. 1989). On the district court order of Judge R. A. Gadbois, Jr., No. 87-03673 (C.D. Cal.Jan. 14, 1988), see Lewis, What Goes Around Comes Around: Can Iran Enforce Awards of the Iran-U.S. Claims Tribural in the United States?, 26 Colum. J. TRANSNAT'L L. 515, 517 n.14 (1988).

${ }^{13}$ Hardenberg, The Awards of the Iran-US Claims Tribunal Seen in Connection with the Law of the Netherlands, 1984 INT'L BUs. LAW. 337, translated from De Uitspraken van het Iran-United States Claims Tribunal naar Nederlands recht bezian, NederLands JuRISTENBLAD, Feb. 11, 1984, at 167.

${ }^{14}$ Van den Berg, Proposed Dutch Law on the Iran-United States Claims Settlement Declaration, A Retatim to Mr. Hardenberg's Article, 1984 INT'L Bus. LAw. 341, translated from Wetsontwerp Iran-Lunted States Claims Tribunal, Een reactie, NederLands Juristenblad, Feb. 11, 1984, at 170.

15 Lake \& Dana, Judicial Review of Awards of the Iran-United States Claims Tribunal: Are the Tribumal's Awards Dutch?, 16 L. \& POL'Y INT'L Bus. 755 (1984).

${ }^{15}$ Stein, Jurisprudence and Jurists' Prudence: The Iranian-Forum Clause Decisions of the IranUnted States Claims Tribunal, 78 AJIL 1, 18 (1984). The thrust of the section that contains this quote, however, is that interpretation of the Algiers Accords is a question of public international law.

${ }^{17}$ Fox, States and the Undertaking to Arbitrate, 37 INT'L \& CoMP. L.Q. 1, 3 (1988). 
Part II applies the conclusions of part I to the Iran-United States Claims Tribunal and concludes that Iran and the United States intended that the Dutch legal system govern the validity of the arbitral process and that the awards of the Tribunal be enforceable as Dutch awards. Moreover, so far as the Netherlands is concerned, the process likely is so governed. The significance of this conclusion also is examined. In particular, I do not believe that the decision to create the Iran-U.S. Claims Tribunal foreshadows a wave of such tribunals. The trend in this century has been to replace claims tribunals with lump sum settlements. Although the Iran-U.S. Claims Tribunal demonstrates that circumstances still may yield a tribunal, the trend likely will continue. ${ }^{18}$ The significance lies rather in the choice of Iran and the United States to have the Dutch legal system review the validity of the arbitrations. That choice reflects the inadequacy of merely distinguishing between interstate and international commercial arbitration to describe the complexities emerging in practice.

In part III, I speculate on what the nature of the Tribunal's work suggests about the way the structure of international dispute resolution evolves and the significance one means of dispute resolution may have for another. A growing body of literature points to the importance for international law and theories of world legal order of understanding the interrelationships between public and private international law. ${ }^{19}$ Examination of the legal character of the Tribunal's work necessarily touches on some aspects of these relationships and illuminates the richness and variety in the international resolution of disputes. Part III posits that the various private, state and interstate mechanisms for the resolution of international disputes have developed in response to the needs of the parties and of the community controlling the mechanisms; that these mechanisms do not operate in isolation but, rather, compete with, and evolve in response to, one another; and that the choices of parties as to the most appropriate mechanism for settling their disputes have led the entire system of dispute resolution to evolve toward greater efficiency and effectiveness.

\section{MOVING BEYOND THE DISTINCTION BETWEEN INTERSTATE AND INTERNATIONAL COMMERCIAL ARBITRATION}

There are various dimensions within which one might analyze, and hence explore the nature of, a dispute resolution process. Consequently, the focus

\footnotetext{
${ }^{18}$ In the case of the Tribunal, the circumstances were disagreement as to a lump sum settlement amount, coupled with the urgent need to conclude the Accords.

On the general trend toward lump sum settlement, see R. LILLICH \& B. WFSTON, INTERNA. tional Claims: Their Settlement by Lump Sum Agreements (1975); and Lillich \& Weston, Lump Sum Agreements: Their Continuing Contribution to the Law of International Clains, 82 AJIL 69 (1988).

${ }^{19}$ See, e.g., Buxbaum, The Role of Public International Law in International Business Transactions, in Public INTERnational LaW aNd the Future WORLd ORder, Liber AMICORUM IN Honor of A. J. ThOMAS, JR. 16-1 (J. J. Norton ed. 1987); Academic Workshop: Should We Continue to Distinguish Between Public and Private International Law?, 79 ASIL Proc. 352 (1985); and Paul, The Isolation of Privale International Law, 7 WIS. INT'L L.J. 149 (1988).
} 
of this article should be clear. For example, although all international arbitration rests upon the consent of the parties, the point in time relative to the dispute when consent is given, and the scope of that consent, may vary considerably. If consent is the focus, an international court and an ad hoc interstate arbitration can be said to involve the same process. These forums differ, however, as to party control over the process, whether that control involves the selection of decision makers or agreement on rules of procedure. This article focuses on two other aspects of the international arbitral process. First, how is the legitimacy or, more relatively, the validity of the arbitral process to be determined? Second, how is the result of the arbitral process to be enforced? ${ }^{20}$ Party control is an internal aspect of the arbitral process. Validity and enforcement can be viewed as involving the evaluation of different legal systems of the external effects to be given the process.

The world internal to an arbitral process is created by the parties. Indeed, municipal arbitration in most countries can be seen simply as an aspect of contract law: the parties to a contract, in this instance an agreement to arbitrate, agree jointly to establish their own means for resolving disputes between them. ${ }^{21}$ Similarly, interstate arbitration and private international arbitration are created and defined by the joint will of the parties. In many cases the parties will cooperate in the arbitral proceedings and voluntarily comply with the award. When the parties cooperate in this way, the private arrangement is autonomous in that no legal system need be involved. ${ }^{22}$ Such an arbitration is a world unto itself. In any arbitration that is not so ideally cooperative, however, many legal systems may become involved. Generally, they will be those that one or both of the parties or the tribunal invokes. Regardless of whether a legal system becomes involved, however, there will remain a contractual world internal to the arbitration defined by the will of the parties, as that intent is interpreted by the arbitrators. ${ }^{23}$

\footnotetext{
20 Although one's conclusions regarding the validity of a given arbitral process will often correlate with those regarding enforcement, they need not do so. See discussion on ICSID in text at notes 34-38 infra.

${ }^{21}$ Parties are motivated to enter into such arrangements municipally because they perceive the process as more likely to be subject to their control and, perhaps, as faster, less expensive and more confidential than that available in the courts. The key legal issue concerns what external limits the relevant municipal legal system places on the freedom of the parties to contract in this way.

${ }^{22}$ Although such autonomy obtains in most municipal legal systems, it is characteristic of municipal arbitration statutes in many Latin American states that even if the parties include a compromissory clause in a contract, the initiation of arbitration must be reviewed and approved by a municipal court. See Garro, Enforcement of Arbitration Agreements and Jurisdiction of Arhitral Trubunals in Latin America, 1 J. INT'L ARB. 293, 310-15 (1984).

${ }^{23}$ The parties, in defining the internal world, may make three significant choices regarding "law." First, the parties may designate the law under which the dispute will be decided. Second, the parties may designate the legal system that supervises the arbitral process. Note that it is ' 'wintal to distinguish between the legal system governing the arbitration as a process and the law applied by the arbitrators to the substance of the dispute to be resolved. Confusion over this distinction is often engendered by the common reference to the legal system governing the arbitration as "the law applicable to the arbitration." Third, the parties may also stipulate the rules of procedure to be used by the tribunal by choosing the procedural law of a state, or, as is
} 
The relationship of the arbitration to the world external to it is governed by a particular legal system, the identity of which depends on the particular relationship in question. ${ }^{24}$ The most important relationships between an arbitration and the world external to it arise when a party attempts to have the arbitration agreement enforced, and any resulting award recognized, set aside or enforced. Knowledgeable parties will draft their arbitration agreement and later structure the proceedings so as to ensure that both the agreement and the award will be valid and enforceable. ${ }^{25}$ Consequently, the internal and external worlds of an arbitration become intertwined because the designers of the former must anticipate the dictates of the latter. ${ }^{26}$

Although interstate arbitration and international commercial arbitration are thus conceptually similar, there are obvious distinctions between them. They typically involve different sorts of parties, disputes and arbitral institutions. A typical interstate arbitration involves a dispute between two sovereign states, for example, over a boundary, and is conducted before either an ad hoc or an institutional panel. ${ }^{27}$ In contrast, the paradigm of interna-

more commonly done, the rules of an arbitral institution such as the ICC. All three choices of law are separate and not necessarily the same.

${ }^{24}$ This internal/external model is expressed as a part of the doctrinal view of others. Clive Schmitthoff, for example, writes, "From the viewpoint of doctrine, arbitration contains two elements, a contractual and a judicial element." Schmitthoff, The Supervisory Jurisdiction of the English Courts, in International Arbitration: Liber Amicorum for Martin Domke 289,289 (P. Sanders ed. 1967). The contractual element springs from the will of the parties and is manifested in the internal world of the arbitration. The judicial element arises in every legal system that is touched by the interaction of the arbitration and the world external to it. Hazel Fox recently wrote, "The institution of arbitration, on the one view, derives its force from the agreement of the parties; on another view, from the State as supervisor and enforcer of the legal process." Fox, supra note 17 , at 1 . The internal/external paradign, at least for the purposes of this study, accurately models the arbitral process.

${ }^{25}$ Professor Park has stated that "an arbitrator must bow to mandatory norms of the country in which he sits." Park, The Lex Loci Arbitri and Intermational Commercial Arbitration, 32 INT'L \& CoMP. L.Q. 21, 23 (1983). It may be more accurate to state that it is to the intent of the parties that the arbitrator must bow. Local law very rarely coerces the arbitrator. Instead, by indicating that a motion to set aside would likely be granted, local law encourages the parties to draft an arbitration agreement that will result in compliance of their arbitration with the mandatory provisions of local law. Indeed, Article V(1)(d) of the Convention on the Recognition and Enforcement of Foreign Arbitral Awards, opened for signature June 10, 1958, 21 UST 2517, TIAS No. 6997, 330 UNTS 3 [hereinafter New York Convention], states that enforcement of an award can be refused if the "composition of the arbitral authority or the arbitral procedure was not in accordance with the agreement of the parties."

${ }^{26}$ For example, recognizing that the parties would want the award to be enforceable in the external world, the UNCITRAL Arbitration Rules, reprinted in 15 ILM 701 (1976) [hereinafter UNCITRAL Rules], an internal set of arbitral rules that parties may adopt, in Article 1(2) provides that those contractual rules are to be superseded by any provision of municipal law that the governing legal system regards as "mandatory."

${ }^{27}$ Because the focus of this article is upon the external view of the process rather than party control, interstate arbitration for the purposes of this article could be ad hoc or within the embrace of an institution such as the International Court of Justice. Although the extent of party control over those processes differs greatly, both types of proceedings are interstate arbitration in the sense that jurisdiction remains consensual. 
tional commercial arbitration involves, for example, a contract dispute between two private entities and takes place under the auspices of a private arbitral institution such as the International Chamber of Commerce. The distinction between interstate arbitration and international commercial arbitration is strengthened by the generally separate identity of the groups of practitioners and scholars dealing with them and these specialists' lack of experience with each other's forums. ${ }^{28}$

Distinctions are useful to the extent that they provide a precise, yet simple, model as a foundation for more complex analysis. The distinction between interstate and international commercial arbitration is no exception. Nevertheless, its limits must be appreciated lest any analysis rest on inaccurate assumptions. To move beyond this distinction requires not only a fuller examination of the two types of international arbitration, but also an understanding of why certain institutions, such as the Iran-United States Claims Tribunal, appear to fit neither ideal type.

\section{Interstate Arbitration}

The internal world of interstate arbitration typically is created and defined by treaty. ${ }^{29}$ The agreement to arbitrate and (where applicable) the treaty establishing the responsible institution are the most relevant treaties. The external world may be of little significance for two reasons.

First, so far as the relationship of the customary international legal system to the arbitration is concerned, the international lawmaking capability of the parties may lead to a merging of the internal/external models. The models can collapse into one because states by their agreements both define the internal world of the arbitration and modify the applicable international law. In this sense, international law leaves the structuring and conduct of the arbitration entirely in the control of the parties. Consequently, the prime question is whether by their agreement to arbitrate the state parties intend to adopt, supplement or, instead, replace entirely the customary interna-

\footnotetext{
${ }^{2} S_{i} t^{\prime}$ e $g ., 1 \mathrm{~J}$. G. Wetter, The InTernational ARbitral Process-Publig and PriVATE, at Xxiv (1979) ("Commercial lawyers regard arbitrations between States as wholly irrelevant; and public international law teachers, advocates and officials view commercial arbitration as an essentially alien process. . ."). However, there is a small group of lawyers and arbitrators who serve in both types of proceedings.

${ }^{29}$ The interstate arbitral process is governed by international law by definition. State parties could agree to remove the dispute entirely from the public international level. For example, state parties in their arbitration agreement could waive their sovereignty and specify that the legal system of a third country will govern the arbitration, just as the latter municipal system might govern private arbitration occurring in that third country. As will be seen, this is precisely what this article contends that Iran and the United States did in the case of the Tribunal. Such an action should be distinguished from those instances in the past when heads of state served as arbitrators of disputes. The arbitration in these cases remained governed by the international legal system. For example, the King of Spain was arbiter in 1906 of a boundary dispute between Honduras and Nicaragua. Nicaragua claimed the award to be a nullity under public international law, an allegation ultimately reviewed and rejected by the International Court of Justice. See Arbitral Award Made by the King of Spain (Hond. v. Nicar.), 1960 ICJ REP. 192 (Judgment of Nov. 18).
} 
tional law that governs such processes. Many agreements to ad hoc arbitration are quite brief and are intended to rest upon the pertinent customary international practice. ${ }^{30}$ Even a brief agreement, however, may raise the question whether aspects of customary practice have been displaced. For example, state parties often agree that the arbitral award shall be final and binding upon them. Nonetheless, customary international law recognizes that either party may declare the award a nullity when the arbitral process does not satisfy certain fundamental norms of fairness. ${ }^{31}$ That a tribunal may not exceed its jurisdiction or be corrupt are examples of such norms. ${ }^{32}$ Although states could agree to remove this customary right, the common phrase "the award shall be final and binding upon the parties" does not necessarily constitute such agreement inasmuch as it is "the award" that is challenged by a declaration of nullity. ${ }^{33}$ An express example of the removal of the customary right can be found in the, in many ways, innovative Convention establishing the International Centre for Settlement of Investment Disputes (ICSID). ${ }^{34}$ That Convention provides a limited mechanism for nullification by a second tribunal ${ }^{35}$ and states that the award "shall not be subject to any appeal or to any other remedy except those provided in this Convention." $" 36$

\footnotetext{
${ }^{30}$ Indeed, this customary practice was so involved in arbitrations in the first half of this century that international legal scholarship devoted a great deal of energy to its codification. See, e.g., Carlston, Codification of International Arbilral Procedure, 47 AJIL 203 (1953).

${ }^{31}$ See generally W. M. REISMAN, NULLITY AND REVISION: THE REVIEW AND ENFORCEMENT OF INTERNATIONAL JUDGMENTS AND AWARDS (1971). Of course, the problem with this right is that often no international court has jurisdiction to review the merits of a state's declaration of nullity; thus, the declaration in effect becomes a justification for that state's refusal to comply with the award.

${ }^{32}$ For an example of corruption in modern times, see the discussion of the U.S.-Venezuelan Claims Commission (1866-1888), 2 J. B. Moore, International Arbitrations to Which the United States Has BeEn a Party 1659-92 (1898).

${ }^{33}$ See W. M. ReISMAN, supra note 31 , at 421 .

${ }^{34}$ Convention on the Settlement of Investment Disputes between States and Nationals of Other States, opened for signature Aug. 27, 1965, 17 UST 1270, TIAS No. 6090, 575 UNTS 159 [hereinafter ICSID Convention]. ICSID is unlike classical interstate arbitration in that one of the parties is likely private. In this sense (and see further text at note $216 \mathrm{mj}$ ra), ICSID, like the Tribunal, is an institution that reflects developments not modeled by the traditional distinction. The ICSID Convention, however, nonetheless stands as a valid example of the proposition in the text because the means of reviewing the validity of awards is decided by the mechanisms provided for in the treaty, and not by reliance on or reference to customary international law doctrines such as declarations of nullity.

${ }^{35}$ ICSID Convention, supra note 34, Art. 52. For the most recent example of such a nullification proceeding, see Amco Asia Corp. v. Republic of Indonesia, No. ARB/81/1: On the Application for Annulment Submitted by the Republic of Indonesia Against the Arbitral Award Rendered on November 20, 1984 (Ad Hoc Committee decision of May 16, 1986, nullifying in part the award on the merits), reprinted in 25 ILM 1441 (1986). For further proceedings in the case, see 83 AJIL 106 (1989).

${ }_{36}$ ICSID Convention, supra note 34, Art. 53(1).

This issue was raised vividly in the recent Judgment of the ICJ on jurisdiction in Military and Paramilitary Activities in and against Nicaragua (Nicar. v. U.S.), Jurisdiction and Admissibility, 1984 ICJ REP. 392 (Judgment of Nov. 26). The United States has refused to recognize the proceedings of the Court on the ground that the Court exceeded its jurisdiction. See Reisman,
} 
The second reason for the general irrelevance of the external world to interstate arbitration is that the immunities normally afforded to states will preclude the involvement of municipal legal systems. Of course, the treaty defining an interstate arbitration could involve municipal courts. For example, although the validity of an ICSID award is resolved within the ICSID process, ICSID awards are enforceable in the national courts of any state party. ${ }^{37}$ In practice, however, resort to municipal courts has been possible only infrequently. Moreover, the agreement of state parties to the use of municipal courts to enforce an arbitral decision is conceptually different from their agreeing that the arbitral process shall be fully subject to a municipal legal system. In the latter case, the municipal system would govern not only enforceability, but also validity. ${ }^{38}$ Involvement of municipal courts in either validity or enforcement rests upon a waiver by states of the immunities such courts normally extend to them.

\section{International Commercial Arbitration between Private Entities}

The extension of traditional municipal arbitration. As to modern forms of international arbitration, Dr. Mann writes:

Although, where international aspects of some kind arise, it is not uncommon and, on the whole, harmless to speak somewhat colloquially, of international arbitration, the phrase is a misnomer. In the legal sense no international commercial arbitration exists. Just as . . every system of private international law is a system of national law, every arbitration is a national arbitration, that is to say, subject to a specific system of national law. ${ }^{39}$

Under this view, international commercial arbitrations are merely private municipal arbitrations that have an international aspect. For such arbitrations, the municipal legal system of the place of arbitration governs whether the arbitral award is valid. ${ }^{40}$ This governing legal system is often termed the

Has thr. Intermational Court Exceded its Jurisdiction?, 80 AJIL 128 (1986). The legal issue is whether or not the United States displaced its customary right to nullify an award for this reason by its agreement in Article 94(2) of the UN Charter "to comply with the decision of the International Court of Justice in any case to which it is a party." See also W. M. REISMAN, supra note 31 , at $420-23$.

${ }^{37}$ ICSID Convention, supra note 34, Art. 54(1). See, e.g., Liberian E. Timber Corp. v. Government of Republic of Liberia, 650 F.Supp. 73 (S.D.N.Y. 1986).

${ }^{3 *} S_{t^{\prime}},{ }^{\prime}, g$. . Maritime Int'l Nominees Establishment v. Republic of Guinea, 693 F.2d 1094, 1100 (D.C. Cir. 1982), cert. denied, 464 U.S. 815 (1983) (distinguishing between U.S. federal court jurisdiction to enforce and jurisdiction generally over ICSID proceedings). See generally Delaume, ICSID Arbitration and the Courts, 77 AJIL 784 (1983).

${ }^{34}$ Mann, Lex Facit Arbitrum, in INTERNATIONAL ARBITRATION, supra note 24, at 157, 159. The de-localized view of arbitration, which challenges Dr. Mann's statement, is considered in the text at notes 50-65 infra.

4" The parties may confuse this general rule by, for example, expressly providing for a lex arbitrt different from that of the designated place of the arbitration, or by holding all proceedings in, or rendering the award in, a country other than the country of the designated place of arbitration. Set Mann, Where Is an Award 'Made'?, 1 ARB. INT'L 107 (1985). 
lex arbitri. "The lex arbitri is not necessarily the law governing the substance of the dispute, nor the procedural rules applied by the arbitrators." 42 Rather, it is the legal system that determines whether the award was arrived at properly. ${ }^{43}$ An award is said to have the nationality of the country where it is rendered; presumably, the place of arbitration is chosen by the parties, or by some other person or institution they have empowered to make that choice. The source of this concept of nationality is territorial; that is, the contract (the agreement to arbitrate) is to be performed within the jurisdiction of a country. ${ }^{44}$

States can take, and have taken, a variety of approaches to their supervision of municipal arbitration. For example, a state may forbid arbitration and refer all disputes to the courts. ${ }^{45}$ States may allow arbitration but dictate the precise procedure to be employed, specify which questions are arbitrable and subject all aspects of the arbitration to judicial review. ${ }^{46}$ Finally, states may allow the parties to choose how the arbitration is to proceed and

${ }^{41}$ See Mann, supra note $39 . \quad \quad 42$ Park, supra note 25, at 23.

${ }^{43}$ Hirsch, The Place of Arbitration and the "Lex Arbitri," 34 ARB. J. 43, 44 (1979).

${ }^{44}$ Other dimensions to governance of the arbitral process exist and the courts of the place of arbitration may be requested to intervene in arbitral proceedings in such other ways. These other relationships generally involve securing judicial assistance in furtherance of the arbitral proceedings, including, inter alia, the appointment of arbitrators and the production of evidence. Generally such matters (in particular, matters relating to the composition of the tribunal) are only within the competence of the courts of the place of arbitration. However, assistance in areas such as interim measures might be available to the parties before courts other than those of the place of arbitration. Finally, it is normally reserved to the courts of the place of arbitration to decide questions about liability of the arbitrators to the parties and, not as exclusively, liability of the parties to the arbitrators. The approaches of the various municipal systems on these more detailed questions vary considerably. See generally Delaume, Court Intervention in Arbitral Proceedings, in Resolving TransNational Disputes Through INTERNA. Tional ARBitration 195 (T. Carbonneau ed. 1984) [hereinafter Resolving Disputes].

${ }^{45}$ Courts in the United States, for example, were hostile at one time to arbitration. See, e.g., United States Asphalt Ref. Co. v. Trinidad Lake Petroleum Co., 222 F. 1006 (S.D.N.Y. 1915). As caseloads have increased in the United States, however, hostility has given way to encouragement. See Burger, Isn't There a Better Way!?, 68 A.B.A.J. 274, 277 (1982).

${ }^{46}$ For example, until quite recently, this second municipal law approach was exemplified by the law of England and Commonwealth countries that followed English practice. This second approach, known as the "special case" or "case stated" procedure, involves much more extensive judicial supervision and control of the arbitration to ensure not only fundamental fairness but also legally correct results. Under the case-stated procedure, either party may demand that the arbitral panel submit a question of law or fact to the courts. The courts may then hold a hearing with full argument from which appeal may be made. The grounds upon which the court addresses the validity of an award are thus considerably broader. However, the approach is no longer favored in the United Kingdom, having been replaced by the 1979 Arbitration Act, a law that moves toward the third approach-an arbitral process substantially more independent of judicial control.

See Mann, Some Recent Developments of the English Law of Arbitration, in IUS INTER NATIONES: FestSChRIFT Für STEFAn Riesenfeld 187, 190 (1983). See also Park, The Influence of National Legal Systems on International Commercial Arbitration: Recent Developments in English Arbitration Law, in Resolving Disputes, supra note 44, at 80; Lord Hacking, Where We Are Now: Trends and Developments Since the Arbitration Act [1979]. 2 J. INT'L ARB. 7 (1985); Jaffe, The Judicial Trend Toward Finality of Commercial Arbilral Awards in England, 24 TEx. INT'L L.J. 67 (1989); and Thomas, The Antaios: The Nema Guidelines Reconsidered, 1985 J. Bus. L. 200. 
limit review to the parties' fundamental interests in a fair process. ${ }^{47} \mathrm{Al}$ though the details vary considerably and differences may be significant, the approach with limited judicial review has come to be the most common.

Under this approach, a statute typically sets forth rules of arbitral procedure. Simultaneously, the statute gives parties the right to displace the statutory procedural scheme by rules of their own choice. Thus, the internal statutory construct is to be applied only if the parties fail to provide otherwise. A frequent caveat in this regard, however, is that certain aspects of the national arbitration law will be mandatory. These mandatory provisions are usually those that ensure fundamental fairness; ordinarily, failure to observe these rules will lead to the setting aside of the award. ${ }^{48}$ The dominance of the notions of nationality of awards based on the place of the arbitration and judicial review limited to concerns of fundamental fairness has been confirmed and bolstered by their adoption in the 1985 UNCITRAL Model Law on International Commercial Arbitration. ${ }^{49}$

Thus, private parties in international commercial arbitration in effect can control the procedure within statutorily defined limits of fundamental fairness. Effective control devolves upon the parties because it is permitted by the sovereign of the place of arbitration. States in interstate arbitration have such control because of their inherent ability to displace by treaty the regime otherwise provided by customary international law.

\footnotetext{
${ }^{47} S_{1 t^{\prime}}$ generally Carbonneau, American and Other National Variations on the Theme of Intermalumal Commeraal Arbitration, 18 GA. J. INT'L \& CoMP. L. 143 (1988) (discussing the evolution of the French, British, Canadian and American approaches).

${ }^{1 \times}$ For example, an arbitral award rendered in the United States may be vacated under $\$ 10$ of the U.S. Arbitration Act:
}

(a) Where the award was procured by corruption, fraud, or undue means.

(b) Where there was evident partiality or corruption in the arbitrators . . . .

(c) Where the arbitrators were guilty of misconduct in refusing to postpone the hearing

.. or in refusing to hear evidence....

(d) Where the arbitrators exceeded their powers . . .

9 U.S.C. $\$ 10(1988)$.

${ }^{4}$ LNCITRAL Model Law on International Commercial Arbitration, Art. 34, adopted June 21, 1985, rprinted in 24 ILM 1302, 1311 (1985) [hereinafter UNCITRAL Model Law]. See Report of the U.N. Commission on International Trade Law on the Work of its Eighteenth Session, 40 UN GAOR Supp. (No. 17), UN Doc A/40/17, Ann. 1 (1985). See generally H. Holtzmann \& J. Neuhaus, a Guide to the UNCITRal Model LaW on International CommerCial ARBITRATION (1988); McNerney \& Esplugues, International Commercial Arbitratimly: The UNCITRAL Model Law, 14 B.C. INT'L \& CoMP. L. REv. 47 (1986); Herrmann, UNCITRIL Adopts Model Law on Intemational Commercial Arbitration, 2 ARB. INT'L 2 (1986); and Broches, The 1995 UNCITRAL Modol Law on International Commercial Arbitration: An Exercise in Intemutronal Legislation, 18 NETH. Y.B. INT'L L. 3 (1987).

On previous regional efforts in Latin America and Europe at a uniform municipal model arbitration law, see Domke, Intemational Arbitration of Commercial Disputes, in 2 INSTITUTE ON PRIVATE INVESTMENTS ABROAD 131, 136-39 (1960).

That the "fundamental fairness" approach is dominant should not be taken to mean that other approaches to municipal governance of the arbitral process do not exist at present. In particular, arbitration in the socialist countries tends to remain very closely supervised by the courts. 
The movement for an anational process. Private parties often are motivated to arbitrate an international dispute for a reason fundamentally different from the reasons that motivate parties to most municipal disputes. On the municipal level, arbitration is attractive because it is perceived to be a desirable alternative to the courts. ${ }^{50} \mathrm{But}$ on the international level, there often is no alternative to arbitration. ${ }^{51}$ In many international situations, neither party will agree to submit all possible disputes to the courts of the other. ${ }^{52}$ Arbitration is preferred over litigation in some third state in part because to ascertain whether procedurally and substantively the courts and legal system would be acceptable would take a tremendous effort, ${ }^{53}$ and also because foreign court proceedings ultimately require extensive, and possibly costly, use of foreign counsel. ${ }^{54}$ Thus, the parties are led to choose arbitration. ${ }^{55}$

Nevertheless, the arbitration alternative does not free the parties entirely from the unknown pitfalls of a foreign legal system; as described above, the system of the place of arbitration will serve as the lex arbitri. The desire to free the parties completely from such pitfalls gives rise to one aspect of the anational movement. ${ }^{56}$

\footnotetext{
${ }^{50}$ The arbitration alternative is particularly attractive for smaller cases where the often time-consuming procedural guarantees and appeal structure of a court system are not of particular importance to the parties.

${ }^{51}$ Similarly, domestic labor arbitration, particularly labor grievance arbitration, arguably "is not a substitute for litigation . . . [but] rather, a device by which the parties agree to accept the judgment of a third party instead of fighting the issues out on the picket lines." Brief for Petitioner 32, Textile Workers Union of Am. v. Lincoln Mills of Ala., 353 U.S. 448 (1957).

${ }^{52}$ Smit, The Future of International Commercial Arbitration: A Single Transnatimal Institution?, 25 COLUM. J. TRANSNAT"L L. 9, 10 (1986) ("Rather than permit international disputes to be settled in national courts, many parties often prefer to submit them to a tribunal that is not part of the governmental structure of a particular state"; id. at 9); de Vries, Intemational Commercial Arbitration: A Contractual Substitute for National Courts, 57 TUL. L. REv. 42 (1982); and Kerr, Commercial Dispute Resolution: The Changing Scene, in LIBER AMICORUM FOR LORD WILBER. FORCE 111,128 (M. Bos \& I. Brownlie eds. 1987).

${ }^{53}$ The generally recognized expertise of English courts in maritime matters is an exception.

${ }^{54}$ In international commercial arbitration, the necessary reliance on foreign counsel can be greatly reduced. Even if a foreign law is applicable to the substance of the dispute, the normal counsel to the parties usually can operate within the arbitral procedure adopted, generally are better suited to deal with the factual basis of the case and, thus, often need to involve foreign counsel only to advise on selected points of the applicable law or supervising legal system.

${ }^{55}$ Moreover, because the motivations for entering into international and wholly municipal commercial arbitration differ, there can be important differences in the two processes and in the directions in which the processes are evolving. For example, because international commercial arbitration can be the only alternative and large amounts may be in dispute, the parties-rather than desiring a streamlined process to ensure speed and reduce costs, as is often the case stated in the municipal context-may seek to design an arbitral process that quite resembles court proceedings, e.g., by providing for discovery or even appeal.

${ }^{56}$ The movement toward an anational system for private international arbitrations has been the subject of a great deal of commentary in recent years. See, e.g., Paulsson, Arbitration Unbound: Award Detached from the Law of its Country of Origin, 30 INT'L \& COMP. L.Q. 358 (1981); Park, supra note 25. The movement has a number of aims. One is that the legal system of the place of arbitration should no longer govern the arbitral process. Rather, it is argued that the system where enforcement is sought should govern. Another aim is clevelopment of a substantive law that is non-national, the "lex mercatoria." See Lando, The "Lei: Mercatoria" in International Commercial Arbitration, 34 INT'L \& CoMP. L.Q. 747 (1985); and Cremades \&
} 
Specifically, although a large number of states allow arbitrating parties to stipulate the procedure to be employed (such as the ICC Rules of Arbitration), this choice does not necessarily assure them a predictable, neutral and effective process. Paulsson offers the following example:

A majority award is rendered. The losing party moves to set it aside on the grounds that the dissenting arbitrator-who one might suppose was nominated by the said party-had not signed the award. The winning party retorts that the contractually stipulated ICC Rules of Arbitration accept majority awards, and do not require a signature by the dissenting arbitrator. The argument would appear to fail, however, since the law of [the place of arbitration] not only requires that all arbitrators sign the award, but provides that any contractual stipulation to the contrary is invalid. ${ }^{57}$

Paulsson points out that whereas the law of the place of arbitration may be totally appropriate for purely domestic arbitrations,

the international businessman who had chosen arbitration under a simple set of rules he thought he understood, having ended up at a seat of arbitration selected only for convenience and not out of admiration for any local legal principles, would be deeply shocked to find that the end result of an expensive process in which he had justly prevailed is the utter nullity of his effort. ${ }^{58}$

Furthermore, to the degree that an arbitral award is only enforceable if it has a nationality, the action of the place of arbitration may render the award a nullity throughout the world. ${ }^{59}$

Plehn. The' $N_{t}$ er "Lex Mercatoria" and the Harmonization of the Laws of International Commercial Transetions, 2 B.U. INT'L L.J. 317 (1984). For recent critical discussions, see Mustill, The New "La Wercatona": The First Tuenty-Five Years, in LIBER AMICORUM FOR LORD WILBERFORCE, supra note 52, at 149; Highet, The Enigma of the Lex Mercatoria, 63 TUL. L. REv. 613 (1989).

The anational arbitration system is similar to the so-called autonomous theory of the nature of private international arbitration. See J. RUBELLIN-DEVICHI, L'ARBITRAGE; NATURE JURIDIQUE, DROIT INTERNE ET DROIT INTERNATIONAL PRIVÉ (1965). In essence, the autonomous theory asserts that private parties may take the place of a state in establishing regimes for the resolution of certain disputes. Yet arbitration often depends on states for support during the arbitral process and for enforcement of resulting awards. See Wetter, The Conduct of the Arbitratw $m, 2$ J. INT'L ARB. 7, 27-34 (1985).

${ }^{37}$ Paulsson, Delocalisation of International Commercial Arbitration: When and Why It Matters, 32 INT"L \& COMP. L.Q. 53, 58 (1983). Paulsson noted that such a provision, albeit "poised for reform," exists in Austria. Id. at 59 n.10. See Melis, Arbitration and the Courts in Austria-internafumal a prcts, in THE ART OF ARBITRATION, Liber AMICORUM FOR PIETER SANDERs 253, 257 (J. C. Schultsz \&. A. J. van den Berg eds. 1982).

5k Paulsson, supra note 57, at 59 .

54 New York Convention, supra note 25. On the Convention, see generally A. J. VAN DEN BERG. THE NEW YORK CONVENTION OF 1958: TOWARD A UNIFORM JUDICIAL INTERPRETATION (1981); Contini, Intemational Commercial Arbitration: The United Nations Convention on the R'cugntion and Enforcement of Foreign Arbitral Awards, 8 AM. J. CoMP. L. 283 (1959); Mirabito, The Unted Natums Conerention on the Recognition and Enforcement of Foreign Arbitral Awards: The Fort Four Years, 5 GA. J. INT'L \& CoMP. L. 471 (1975); Sanders, A Twenty Years' Review of the Comusthon on the Recognition and Enforcement of Foreign Arbitral Au'ards, 13 INT'L LAW. 269 (1979); and Springer, The United Nations Convention on the Recognition and Enforcement of Foreign A hitrel , tuards, 3 INT'L LAw. 320 (1969). 
The anational movement challenges the burden placed on international commercial arbitration by such vagaries of municipal arbitration. Municipal arbitration statutes were originally drafted, quite understandably, with municipal disputes in mind. Their standards of judicial review followed municipal norms of fairness. The anational movement opposes the tendency of the enforcing state to require that the award have a nationality. Under its approach, an annulment at the place of arbitration would no longer be a global annulment and, in effect, the significance of an award would be determined by the state where enforcement is sought. ${ }^{60} \mathrm{~A}$ common metaphor is that the award "floats" until enforcement seeks to anchor it within a given legal system. Anational arbitration is referred to also as "delocalized arbitration."

Critics of the anational approach argue that arbitral awards must have a nationality; otherwise, " $[t]$ he paradox of a legal obligation independent of a legal order suggests Athena springing full-blown from the head of Zeus . . . ." Proponents counter that no one questions that the validity of an international contract should not turn upon the approval of the state where the contract was formed, particularly when the contract has no other connection with that state. Similarly, the lex arbitri should not be permitted to dictate the determinative view of an award because there are often few connections between the place of arbitration and the parties, the dispute or the assets that may satisfy the award.

In support of the enforceability of anational awards under the Convention, see Lake \& Dana, supra note 15, at 790. Opposed, see A. J. VAN DEN BERG, supra, at 28-40. A subcommittee of the American Arbitration Association concluded that "the convention should apply to delocalized arbitration [another term for anational arbitration], but it is to be expected that delocalized awards will be given special scrutiny in the courts of the United States." Sub-Committee on Delocalized Arbitration of the Law Committee of the American Arbitration Association, Report 12 (Feb. 14, 1984) [hereinafter AAA Report]. If, instead of an appropriate law applied fairly, the award were set aside in a country "without a tradition of judicial independence . . . merely to please the bureaucracy . . . [e]nforcement of such an award [elsewhere] would seem neither improper nor inappropriate." Park, supra note 25, at 27-28.

${ }^{60}$ A related objective of the approach is to encourage courts to abstain from applying their law to an international commercial arbitration simply because the award was rendered in that state. An often-argued example is the decision on the appeal of an ICC award, Gölaverken Arendal v. Libyan General National Maritime Transporl, Feb. 21, 1980; for an English translation of extracts, see Paulsson, supra note 56, at 385. The Paris Court of Appeal noted that even though the place of arbitration was Paris and the award had been rendered in Paris, Article 11 of the ICC Rules (unaltered by the parties) provided for not even a subsicliary reference to French law: "the place of the arbitral proceedings, chosen only in order to assure their neutrality, is not significant; it may not be considered an implicit expression of the parties' intent to subject themselves, even subsidiarily, to the loi procédurale française." The court concluded that since the award had been "rendered in accordance with proceedings which are not those of French law and which have no attachment whatsoever to the French legal order since the two parties are foreigners, and since the contract was signed and was to be performed abroad, [it] may not be considered French." Id. at 386. In this sense, the rhetoric of the anational movement echoes the motivations expressed in the shift in U.S. choice of law from localizing factors to interest analysis.

${ }^{6}$ Park, supra note 25, at 27. See also Redfern, The Arbitration Betucen the Government of Kuutait and Aminoil, 55 BRIT. Y.B. INT'L L. 78 (1984). 
Although nationality of awards may not be a logical necessity, as some critics seem to suggest, there are practical reasons that support the present connection between the rendering of an award and the legal system of the place of arbitration. Most importantly, this connection provides a means for timely judicial review of arbitral awards. Unlike the formation of a contract, the rendering of the award is the final act in arbitral proceedings. Consequently, most municipal arbitration statutes require that a motion to set aside the award must be filed with local courts within a short period-quite often within 3 months of the rendering of the award. ${ }^{62}$ This procedure accomplishes two practical goals. First, the losing party need challenge the award only once and therefore is not "forced to litigate issues such as arbitrator corruption in all States where it has assets." 63 Second, and more important, the judicial review of at least certain issues takes place at the most appropriate place and time: where the arbitrators and records are likely to be present and while the recollections and evidence are fresh.

Moreover, this aspect of the anational movement's concerns, although interesting, has been, and will increasingly be, of little practical significance. First of all, prudent parties will desire, and thus intend, that their arbitration be governed by a legal system so that court assistance during the proceedings, even though often limited, will be available, and so that the enforceability of the award will be strengthened by the support of the appellation of a nationality. Second, and more important, the problem behind the main impetus to the anational movement, "peculiar and unexpected local norms," is being resolved in ways other than that suggested by the movement's adherents: in part, by the general harmonization of municipal arbitration statutes, and especially, by the trend toward the adoption by states of special statutes that cover international commercial arbitration alone and exclude peculiar local norms. ${ }^{64}$ The recently adopted UNCITRAL Model

$" S_{t_{*}}, g_{*}$, UNCITRAL Model Law, supra note 49, Art. 34(3).

is Park, supra note 25, at 51. See also A. J. VAN DEN BERG, supra note 59, at 30.

"For example, Lord Elwyn Jones, in introducing the bill that eventually eliminated the British "case stated" procedure, supra note 46, explained: "The purpose [of the bill] is to remove certain legal obstacles which at present stand in the way of London being used to its full potential as an international centre for arbitration." See Kerr, supra note 52, at 124. See also Bentil, Maling England a More Attractive Venue for International Commercial Arbitration by Less Jrthutul (tersight, $5 \mathrm{~J}$. INT'L ARB. 49 (1988). Indeed, the commercial value of being a center of arbitration is generally believed to have spurred this global transformation of municipal arbitration laws.

France, whose courts are argued to have employed anational reasoning in regard to an arbitration (s $z$ supra note 60 ), shortly thereafter adopted such a statute. See Audit, $A$ National C.rilyturtun of Intmutional Commercial Arbitration: The French Decree of May 12, 1981, in REshviNc. Disputes, supra note 44, at 117. See also Carbonneau, supra note 47, at 167-73; Carbumneau, Thi Elaboration of a French Court Doctrine on International Commercial Arbitration: A Stuls m Lihrial Civilian Judicial Creativity, 55 TuL. L. REv. 1 (1980); Bellet, The Evolution of Fenel Judual Virus on Intemational Commercial Arbitration, 34 ARB. J. 28 (1979).

On the other hand, Belgium has passed a law freeing international arbitrations entirely, i.e., mahing them anational. $S^{\prime \prime} t^{\prime}$ van Houtte, La Loi belge du 27 mars 1985 sur l'arbitrage international, IYSG REVUe dE L'ARbitrage [REv. ARB.] 29 (1986); Vanderelst, Increasing the Appeal of B. Igtum a an Int matronal Arbutration Fortum?-The Belgian Law of March 27, 1985 concerning the thuulne nt of Arlitral Awards, $3 \mathrm{~J}$. INT'L ARB. 77 (1986). 
Law on International Commercial Arbitration should encourage this approach, as it applies only to international commercial arbitration and affords limited, and only generally accepted, grounds for the setting aside of, or refusal to enforce, an award. ${ }^{65}$

\section{International Arbitration between a State and a Private Entity}

Arbitrations that typically are neither interstate nor private illuminate the inadequacy of distinguishing between these processes on the basis of the parties or issues involved, or the public or private nature of the surrounding institutional arrangement. Most such arbitrations involve proceedings between a state and a private entity, an increasingly common configuration of parties and the one faced for the most part by the Iran-United States Claims Tribunal. ${ }^{66}$ In these cases, is the arbitration governed by the international legal system as for interstate arbitration, or by a municipal legal system as for international commercial arbitration? Awards reaching one or the other conclusion have been rendered. ${ }^{67}$

${ }^{65}$ See UNCITRAL Model Law, supra note 49, Art. 34. "To the extent that the UNCITRAL, draft Model Law . . . with its very limited grounds for review is adopted. [the] reasons for seeking to delocalize arbitration would be reduced in persuasiveness." AAA Report, supra notc 59 , at 6 . "Article 34 takes into account the 'mobility' of international commercial arbitration and reduces the legal relevance of the chosen place of arbitration. . . . [I]t contributes to what one may call 'soft delocalization'." Herrmann, The British Columbia Enactment of the UNCITRAL Model Law, in UNCITRAL ARbitration Model in CANAda 65, 70 (R. Paterson \& B. Thompson eds. 1987). As to the grounds for refusing to enforce an award under the UNCITRAL Model Law, see Ungar, The Enforcement of Arbitral Au'ards Under UNCITRAL's Model Law on International Commercial Arbitration, 25 Colum. J. TRANSNAT'L L. 717 (1937).

${ }^{66}$ See Böckstiegel, States in the International Arbitral Process, 2 ARB. INT'L 22 (1986).

${ }^{67}$ A caveat to the significance of these arbitral awards can be found in Judge Lagergren's comment in British Petroleum, infra note 76, that the "Tribunal is not competent to establish conclusively the nationality of its Award, for this can only be decided by the courts of [the place of arbitration] and of other jurisdictions in which the enforcement of the Award may be sought." 53 ILR at 309. Notably, in this regard the somewhat ambiguous LLAMCO award, infra note 85 , was later the subject of extensive municipal litigation. Implicit in that subsequent litigation, despite the ambiguity of the award itself, is the seemingly unquestioned assumption that the arbitration was governed by Switzerland's legal system. The Swiss Federal Supreme Court, in an action relating to enforcement, noted that "the appeal for annulnent permissible under the laws of Geneva was not filed." Libya v. Libyan American Oil Co. (Swiss Federal Supreme Ct., June 19, 1980), reprinted in 20 ILM 151, 154 (1981). (As to Swiss laws on the execution issue presented, see generally Lalive, Swiss Law and Practice in Relation to Measures of Execution against the Property of a Foreign State, 10 NETH. Y.B. INT'L L. 153 (1979).) Moreover, in a later enforcement action in U.S. courts, Libya itself characterized the award as Swiss, contending that "the Swiss judgment has, in effect, set aside or suspended L1AMCO's arbitral award"; while the United States, as amicus curiae, argued that the award was a foreign arbitral award enforceable under the New York Convention. Brief (June 16, 1980) and Supplemental Memorandum (Nov. 7, 1980) of the United States as amicus curiae in Libyan American Oil Co. v. Socialist People's Libyan Jamahirya, reprinted in $20 \mathrm{ILM} 161$ and 164, 165 (1981). The court of appeals, apparently in reliance on the amicus brief, 684 F.2d 1032 (D.C. Cir. 1982), vacated the judgment of the U.S. district court, 482 F.Supp. 1175 (D.D.C. 1980), which also had assumed that the award was the result of foreign rather than international arbitration, but had nonetheless declined to recognize or enforce the award by reason of the act of state doctrine. The award was also recognized in France and Sweden. See Procureur de la République v. 
The classic discussion of this question in a case is the 1958 arbitration, Saudi Arabia v. Arabian American Oil Co. (ARAMCO). ${ }^{68}$ The tribunal concluded that "[a]lthough the present arbitration was instituted, not between States, but between a State and a private American corporation, the Arbitration Tribunal is not of the opinion that the law of the country of its seat [Switzerland] should be applied to the arbitration."69

The $A R A M C O$ tribunal's conclusion rested in large part on great deference to the sovereign nature of states.

The jurisdictional immunity of States . . excludes the possibility, for the judicial authorities of the country of the seat, of exercising their right of supervision and interference in the arbitral proceedings which they have in certain cases. . . .

Considering the jurisdictional immunity of foreign States, recognized by international law in a spirit of respect for the essential dignity of sovereign power, the Tribunal is unable to hold that arbitral proceedings to which a sovereign State is a Party could be subject to the law of another State. ${ }^{70}$

This deference to sovereignty reflected the tribunal's estimation of the deference states afforded one another at that time:

It is true that the practice of the Swiss Courts has limited the jurisdictional immunity of States and does not protect that immunity, in disputes of a private nature, when the legal relations between the Parties have been created, or when their obligations have to be performed in Switzerland. The Arbitration Tribunal must, however, take that immunity into account when determining the law to be applied to an arbitration which will lead to a purely declaratory award. By agreeing to fix the seat of the Tribunal in Switzerland, the foreign State which is a Party to the arbitration is not presumed to have surrendered its jurisdictional immunity in case of disputes relating to the implementation of the "compromis" itself. ${ }^{71}$

Having decided that the Swiss legal system did not govern the arbitration, the panel structured the internal world of the arbitration along the lines of an interstate arbitration. "In such a case, the [internal procedural] rules set forth in the Draft Convention on Arbitral Procedure, adopted by the International Law Commission of the United Nations . . ., should be applied by analogy."72

On the other hand, in 1963 the arbitrator in Sapphire International PetroLtums $v$. National Iranian Oil Co. decided that the legal system of the place of

Société LIAMCO (Trib. gr. inst. Paris 1979), reprinted in 106 JOURNAL DU DROIT INTERNATroN גL [JDI] 857 (1979); Libyan American Oil Co. v. Libya (Ct. App. Svea, June 19, 1980), nf hunt ll in Englash in 20 ILM 893 (1981).

${ }^{14}$ Saudi Arabia v. Arabian American Oil Co. (ARAMCO), reprinted in 27 ILR 117 (1958)

(Sauser-Hall, Badawi/Hassan, Habachy, arbs.).

"II. at 155 .

7l 7 . at 156 .

${ }^{70} I d$. at $155-56$.

${ }^{72} \mathrm{Id}$. 
arbitration would govern the arbitration. ${ }^{73}$ The parties had agreed to a precise and detailed arbitration clause to be used after an optional conciliation procedure. Cavin, the sole arbitrator, concluded that the parties had "unequivocally shown their mutual desire to use arbitration in order to obtain a decision which will settle once and for all their possible differences." ${ }^{74}$ In Cavin's opinion, this desire indicated that the decision "should be subject to the supervision of a State authority, such as the judicial sovereignty of a State."75

British Petroleum Exploration Co. v. Libyan Arab Republic ${ }^{76}$ was one of three arbitrations between Libya and the nationals of a foreign state that arose out of the Libyan oil nationalizations of the early $1970 \mathrm{~s} .{ }^{77}$ In British Petroleum, Judge Lagergren quoted the ARAMCO opinion at length but then stated that the tribunal "cannot share the view that the application of municipal procedural law to an international arbitration like the present one would infringe upon such prerogatives as a State party to the proceedings may have by virtue of its sovereign status."78 Indeed, Judge Lagergren contended, "By providing for arbitration as an exclusive mechanism for resolving contractual disputes, the parties to an agreement, even if one of them is a State, must . . . be presumed to have intended to create an effective remedy"; and the effectiveness of a remedy is certainly greater when the "award [is] founded on the procedural law of a specific [municipal] legal system."79

Texaco Overseas Petroleum \& California Asiatic Oil Co. v. Libya $(\text { TOPCO })^{80}$ involved an arbitration clause identical to the one in British Petroleum, yet reached the opposite result of British Petroleum and Sapphire. Professor Dupuy, the sole arbitrator, cited the result in Sapphire with approval but

\footnotetext{
${ }^{73}$ Sapphire International Petroleums v. National Iranian Oil Co., reprintod in 35 ILR 136 (1963) (Cavin, sole arb.). See also Suratgar, The Sapphire Arbitration Au'ard, the Procedural Aspects: A Report and a Critique, 3 Colum. J. Transnat'L L. 152 (1964).

${ }^{74}$ Sapphire, 35 ILR at 168. ${ }^{75}$ Id. at 169.

${ }^{76}$ British Petroleum Exploration Co. v. Libyan Arab Republic (Award on the Merits), reprinted in 53 ILR 297 (1973) (Lagergren, sole arb.). A further award was renclered by Lagergren on Aug. 1, 1974, addressing plaintiff's motion to reopen the proceedings; reprinled in id. at 375 .

${ }^{77}$ See von Mehren \& Kourides, International Arbitrations between States and Foreign Private Parties: The Libyan Nationalization Cases, 75 AJIL 476 (1981). The three arbitrations are significant generally and to this discussion specifically because "[i]t is rare in international arbitration for three arbitrations, with virtually identical factual and legal contexts, to arise and be heard by distinguished international jurists, and to result in awards that thereafter become part of the public domain." Id. at 490.

${ }^{78}$ British Petroleum, 53 ILR at 309.

${ }^{79}$ Id. In support of his holding, Judge Lagergren cited Sapphire and Alsing Trading Co. \& Svenska Tändsticks Aktiebolaget v. The Greek State, reprinted in 23 ILR 633 (1954) (Python, sole arb.). On Alsing, see generally Schwebel, The Alsing Case, 8 INT'L \& CoMP. L.Q. 320 (1959).

${ }^{80}$ Texaco Overseas Petroleum Co. \& California Asiatic Oil Co. v. Libyan Arab Republic (Award on the Merits) (1977), reprinted in 17 ILM 1 (1978) (Dupuy, sole arb.). French original of part II of the Award on the Merits, reprinted in 104 JDI 350 (1977). Professor Dupuy at an earlier stage rendered an award on his jurisdiction. TOPCO (Preliminary Award), reprinted in 53 ILR 393 (1975) (Dupuy, sole arb.). See further Lalive, Un Grand Arbitrag' Pétrolier entre un Gouvermement et deux sociétés privées étrangères, 104 JDI 319 (1977).
} 
distinguished the case on two bases: (1) Sapphire had involved a state enterprise rather than, as was the case in TOPCO, the state itself; and (2) the plaintiff in Sapphire had sought an enforceable judgment, while the plaintiffs in TOPCO "have indicated that they intend that the present arbitration should be an arbitration on matters of principle." 81 Even if a final judgment had been sought, Dupuy suggested that he would have discounted this fact because it was "a consideration relating to enforcement, which is not within the jurisdiction of the Arbitrator." 82 Dupuy then cited the reasoning in $A R A M C O$ with approval, adding that its conclusion was further supported in TOPCO because the President of the International Court of Justice had appointed the sole arbitrator ${ }^{83}$ and the parties had not objected to Dupuy's formulation of the tribunal's rules of procedure, which, inter alia, provided that "the arbitration shall be governed by these Rules of Procedure to the exclusion of the local law." 84

The third and last Libyan oil nationalization case was Libyan American Oil Co. v. Libyan Arab Republic (LIAMCO). ${ }^{85}$ Of the three, LIAMCO was the most unclear about whether the arbitration was governed by the international legal system or by that of the place of arbitration. Mahmassani, the sole arbitrator, wrote only that, given the failure of the parties to agree otherwise, "the City of Geneva shall be the official seat of arbitration" and that "the arbitrator will employ the 1958 United Nations Draft Convention on Arbitral Procedure." 86 The first statement could be read to suggest that the Swiss legal system governed the arbitral process, while the second statement could be read to suggest equally that the international legal system governed. ${ }^{87}$

\footnotetext{
$"$ TOPCO, 17 ILMI at 8 .

${ }^{82} I d$.
}

${ }^{\mathrm{K}, 3}$ Dupuy distinguishes Sapphire, whose sole arbitrator was to be appointed by the President of the Swiss Federal Tribunal. He implies mistakenly, however, that this designation was an expressly stated basis for the conclusion reached in Sapphire. Id.

* 1, at 9.

"s Libyan American Oil Co. v. Libyan Arab Republic (1977), reprinted in 20 ILM 1 (1981) (Mahmassani, sole arb.).

xir Irl. at 43 .

${ }^{47}$ Von Mehren \& Kourides, assuming that Swiss law governed the arbitration, found it interesting that Libya did not challenge the award "because the arbitral procedure was not the law of the situs." Von Mehren \& Kourides, supra note 77, at 509. However, under the vast majority of municipal arbitration statutes, parties may choose their own internal rules of procedure as long as those rules are not inconsistent with the mandatory provisions of the arbitration statute involved. Thus, there is nothing inherently challengeable about the choice by Mahmassani of the United Nations Draft Convention on Arbitral Procedure. The only reason for challenge on the basis stated would be failure to comply with mandatory provisions, such as registration of the award.

Lake and Dana conclude that the arbitration "must be regarded as a-national" because the choice to use the Draft Convention on Arbitral Procedure was made, according to Mahmassani, "independently of the local law of the seat of arbitration." Lake \& Dana, supra note 15, at 804. Again, however, Mahmassani's statement is ambiguous in that it does not say that the procedural rules chosen would be applied even if they were-in some particularities-contrary to local law. Rather, Mahmassani cites Sapphire only to support the principle that the rules of procedure are chosen independently of local law. 
Arbitrators and commentators have cited one or the other of these cases to justify a variety of inconsistent propositions about the legal system that should govern such arbitrations. Significantly, however, in all of the cases the arbitrators approached the facts before them in the same basic manner: they sought to ascertain the intent of the parties, which not once was set forth clearly in an express provision. Thus, the arbitrators examined subsidiary factors for evidence of intent. It is the facts, or perhaps the starting presumptions of the arbitrators, but not the test of which legal system governs, that led the cases to different results.

As to the difference in starting presumptions of the arbitrators, the 15 years between the ARAMCO and British Petroleum awards are crucial. That period saw dramatic changes in legal doctrine, which necessarily influenced what the arbitrators thought to be the basic intent of the parties. The 1958 $A R A M C O$ award found that even though Saudi Arabia had agreed to making Switzerland the seat of the tribunal, it could not thus be presumed to have surrendered its immunity from Swiss oversight of the arbitration. ${ }^{88}$ The 1973 British Petroleum award, on the other hand, emphasized that even though one of the parties was a state, it must have intended to create an effective remedy. ${ }^{89}$

This change in attitude from ARAMCO to British Petroleum can be explained in two ways. First, the panel in ARAMCO noted repeatedly that the parties sought only a declaratory judgment. In this sense, they possibly attached less importance to the enforceability of the award. ${ }^{90}$ The second and more significant explanation is the emergence of the doctrine of restrictive sovereign immunity in many municipal legal systems during this same period.

The resolution of international legal disputes finds expression in many mechanisms: the International Court of Justice, claims commissions, private

At the other end of the spectrum, Redfern suggests that Mahmassani followed the approach of Dupuy in TOPCO and regarded LIAMCO only as subject to public international law. Redfern, supra note 61 , at 82 .

${ }^{88}$ ARAMCO, 27 ILR at 156.

${ }^{89}$ British Petroleum, 53 ILR at 309.

Dupuy, the sole arbitrator in TOPCO, did not state his view on this point but, rather, confused his jurisdiction to consider enforceability generally with consideration of enforceability as a circumstance evidencing the parties' choice of the legal system to govern the arbitration. In addition, it seems inconsistent that Dupuy cited the number of parties to the ICSID Convention to support his conclusion that UN General Assembly Resolution 1803 continued to reflect the proper standard of compensation in expropriation, 17 ILM at 30, but did not cite the same circumstances to support the apparent willingness of states to enter into enforceable arbitral arrangements.

${ }^{90}$ Dupuy in TOPCO also noted that the enforceability of the award in that arbitration was not of practical significance, as the "present arbitration should be an arbitration on matters of principle." 17 ILM at 8. What Dupuy passed over, however, is that, as in British Petroleum, the award as to legal principles was only the first stage of an arbitration that ultimately was to decide upon the requested relief of restitution or damages. Thus, the TOPCO arbitration ultimately was of more than declaratory character. See von Mehren \& Kourides, supra note 77, at 490-96. 
arbitration and municipal courts. The development of these mechanisms is rarely coordinated, yet modifications in any one may, as a stone dropped into water, ripple throughout. The panel in $A R A M C O$ noted in 1958 that "[i]t is true that the practice of the Swiss Courts has limited the jurisdictional immunity of States . . . .91 It is also true, however, that 1958 marked only the beginning of widespread implementation of the restrictive theory of sovereign immunity. Prior to 1952, a U.S. national's primary mechanism for raising a claim against a foreign government was diplomatic protection. $^{92}$ Indeed, the institution of an action in U.S. courts against a foreign state did not become free of executive comment until passage of the Foreign Sovereign Immunities Act in $1976 .{ }^{93}$ Although acceptance of the restrictive theory, particularly as to enforcement, is by no means universal, transformations similar to that in the United States occurred in other countries during these decades. ${ }^{94}$ Consequently, as the traditional distinctions between a state party and a private party have become less relevant to certain kinds of activity, the likelihood of an effective municipal remedy against state parties has increased dramatically for private parties engaged in international business. ${ }^{95}$

At the same time, companies have often been reluctant to enter into schemes requiring investment in a foreign country unless that investment could be protected. ${ }^{96}$ In negotiating arbitration clauses, companies and states are seeking an alternative to the local courts. This alternative can be truly acceptable to private parties only if it provides an effective remedy. Thus, one would expect the circumstances described to lead the parties to choose the legal system of the place of arbitration to govern the arbitral process.

Finally, it should be noted that Lake and Dana offer a third possible legal characterization of arbitrations between states and private entities. They

"I ARAMCO, 27 ILR at 156.

${ }^{92} S_{t '}$ Z \& F Assets Realization Corp. v. Hull, 311 U.S. 470, 487 (1941).

's 28 U.S.C. $\$ \$ 1330,1332,1396,1441,1602-1611$ (1982). During the period 1952-1976, suits could be instituted with the filing by the Department of State of its suggestions on immunity with the court. For a concise history of U.S. practice, see Alfred Dunhill of London, Inc. v. Republic of Cuba, 425 U.S. 682,698 (1976).

"S'r, t.g., United Kingdom State Immunity Act 1978, ch. 33, reprinted in 17 ILM 1123 (1978); Canadian Act to Provide for State Immunity, ch. 95 (1982), reprinted in 21 ILM 798 (1982); European Convention on State Immunity (1972), 1972 ETS 74, reprinted in 11 ILM 470 (1972); Australian Foreign States Immunities Act 1985, reprinted in 25 ILM 715 (1986).

On the current state of sovereign immunity doctrine, see Trooboff, Foreign State Immunity: Emt rging Consensus on Principles, 200 Recueil des Cours 235 (1986 V). On an agreement to arbitrate as a waiver of sovereign immunity from execution, see id. at 388; Fox, supra note 17, at 10; and Blessing \& Burckhardt, Sovereign Immunity-A Pitfall in State Arbitration?, in Swiss Essays on InTERNATIONAL ARBitration 107 (C. Reymond \& E. Bucher eds. 1984).

43 Böckstiegel, supra note 66 , at 27.

"16 Although I believe this proposition, as qualified, is true, I also note that I am not aware of empirical support for the assertion that business acts cautiously in regard to foreign investment. The qualification "often" recognizes that corporate behavior likely turns also upon the competition within the industry in question and the institutional memory of the specific corporation. 
regard arbitrations such as TOPCO and $A R A M C O$ as anational, ${ }^{97}$ a conclusion that apparently rests on the assumption that all "denationalized" arbitration is anational arbitration. This assumption, however, fails to distinguish between two forms of denationalized arbitration: anational arbitration and interstate arbitration. Anational arbitration is denationalized in the sense that it is freed at least somewhat from the supervisory jurisdiction of the legal system where the award was made. Yet the proponents of anational arbitration do not intend that such proceedings also be freed from the jurisdiction of legal systems of states where enforcement may be sought. Interstate arbitration, on the other hand, is totally denationalized. ${ }^{98}$ It is governed by the applicable international legal regime and involves municipal courts only to the degree agreed to by the parties. The ARAMCO tribunal concluded that Saudi Arabia could not be presumed to have intended to "be subject to the law of another State"; but to regard the ARAMCO award as anational would surely subject Saudi Arabia to the legal system of another state-the enforcement state.

\section{The Distinction Distilled: Sovereign Immunity and Intent}

The latitude parties enjoy over their agreement to arbitrate allows for great variety in the interstate and international commercial arbitral processes. Private parties choose the place of arbitration and the applicable rules of arbitral procedure, including special rules such as provisions for the production of evidence. States may choose an ad hoc arbitration governed by an international regime (such as in $A R A M C O$ ) or they may waive at least a part of their immunity and join the private parties in choosing a lex arbitri. The consideration arguably most influencing these choices, particularly the agreement of a state to review of the arbitral process by a municipal legal system, is the enforceability of the resulting award. ${ }^{99}$ The types of parties and disputes involved often suggest the process preferred by the parties, and thus our intuitive distinction between an interstate and a private commercial process may often be confirmed.

In any particular case, however, the choice suggested as most likely by the circumstances may not be the choice in fact adopted by the parties. Consequently, although it may be convenient or useful to describe a particular type of process as interstate or private, the distinction should be used with care. To determine the legal character of an arbitration, the relevant ques-

\footnotetext{
97 Lake and Dana first state that $A R A M C O$ and TOPCO were "denationalized" proceedings, supra note 15, at 774. They later conclude that the Iran-U.S. Claims Tribunal, like the International Court of Justice, is "a 'denationalized' adjudicating body, whose actions are governed by the treaty creating it and by its own rules, but not by any national arbitration law," id. at 779. They ultimately conclude that because the Tribunal (and implicitly ARAMCO and TOPCO also) is denationalized, its awards are anational, $i d$. at 789.

${ }^{98}$ A similar mixing of these two forms of denationalized arbitrations occurs in Redfern, supra note 61 , at 77 (text at note 25 ) and 79-83.

${ }^{99}$ Although it must be remembered that a given country may not be a party to the New York Convention, while a state may have frozen assets at its disposal to set off against a public international award.
} 
tions are: what legal system did the parties intend to govern the validity of the arbitral process? and, if a state is involved, to what degree does the agreement of the parties embody a waiver of the state party's immunities? A legal system will govern the validity of the arbitral process. But inasmuch as the parties themselves choose that legal system, the key factor is their intent.

The awards discussed above suggest several factors that might indicate the intention of the parties about the governing legal system. The content and structure of the arbitration agreement as a whole may serve as such evidence. Thus, Cavin cited the provision for an optional conciliation procedure and the detailed procedural provisions of the arbitration agreement in Sapphire to support his conclusion that the parties desired a final solution and that the law of the place of arbitration applied. ${ }^{100}$ Likewise, the national or international nature of the appointing authority could be evidence of intent. In the TOPCO case, Professor Dupuy found such evidence in the parties' failure to object to the Rules of Procedure he had formulated. ${ }^{101}$ In addition to these factors, Delaume suggests that the more the legal system of the place of arbitration reviews both the fairness and the legal correctness of the arbitration, the more likely it is that the state party did not intend to submit itself to that system. ${ }^{102}$

Subsidiary factors evidencing intent need not be examined when the parties have stated it unequivocally in the arbitration clause, even if the subsidiary factors mentioned above indicate the opposite intent. In Kuwait and the American Independent Oil Co. (AMINOIL), ${ }^{103}$ the arbitrators noted that the arbitration agreement provided (1) that the proceedings were to be subject to "any mandatory provisions of the procedural law of the place where the arbitration is held"; ${ }^{04}(2)$ that the parties "expressly waive[d] all rights of recourse to any Court, except such rights as cannot be waived by the law of the place of arbitration"; ${ }^{105}$ and (3) that the "seat of the arbitration shall be Paris." 106 On the basis of these provisions, the panel concluded that "[w]ith regard to the law governing the arbitral procedure in the broadest sense, it is not open to doubt that the Parties have chosen the French legal system."107 Without such clear provisions in the arbitral agreement, the subsidiary factors would have suggested the opposite result. In particular, a state rather than a state enterprise was involved, the dispute

\footnotetext{
${ }^{1+* 1}$ Sapphire, 35 ILR at 168-69.

${ }^{101} S_{t+}$ text at note 84 supra and TOPCO, 17 ILM at 9.

1"2 Delaume, Arbitration with Goternments: "Domestic" v. "International" Awards, 17 INT'L L.1w. 687, 689 (1983):

In this connection, it may be appropriate to recall that the English Arbitration Act of 1979, abolishing the special case procedure, was enacted for the purpose, among others, of assuring foreign states that ... they would no longer have to fear that the submission implied acceptance of the judicial supervisory authority of the English Court.

Sit AAA Report, supra note 59, at 5-6.

lus Kuwait and American Independent Oil Co. (1982), reprinted in 21 ILM 976 (1982)

(Reuter, Fitzmaurice, Sultan, arbs.).

i"' Art. IV(1), id. at 980 .

${ }^{105}$ Art. V, id.

int Art. IV(3), id.

${ }^{107} \mathrm{Id}$. at 999.
} 
involved rights in natural resources, and the President of the International Court of Justice had been called upon to appoint the presiding arbitrator. ${ }^{108}$

Similarly, their intent would be unmistakable if the parties chose rules such as those of the ICC, since they presuppose that the parties desire a private international arbitral process. Indeed, under the law of several countries, a state's agreement to arbitration within that country's municipal scheme constitutes a waiver of immunities. ${ }^{109}$ Normally, the intent to place the arbitration within the municipal scheme is apparent because the parties have adopted nationally promulgated private arbitration rules, such as those of the American Arbitration Association, or transnationally promulgated private arbitration rules, such as those of the ICC.

The transition from basing analysis on categories rather than intent will not be as simple for arbitral panels as might initially be thought. Analysis based on intent will require the interpreter of a treaty to be suspicious of traditional pigeonholes for international structures because the parties by their treaty may have constructed a new type of structure. This is not an easy task because an interpreter's preconceived notions of what the parties should have intended can blind the interpreter to what the parties say they intended. In both law and science one can undertake to construct a taxonomy; but in law the categories that can be said to be naturally apparent flow from changing circumstances such as the organization of society and the ability of those within the society to interact. This organization is constantly challenged and this ability thus far has increased without major interruption. The challenges may require change in legal categories; often the increasing ability to interact itself provides the means. To squeeze innovative efforts into traditional categories is to constrain society's ability to adapt. The danger that the innovative intent of the parties will be frustrated is particularly acute at a time when the relatively rapid evolution of international law processes may make preheld notions also out-of-date. Treaties are a prime source of innovation in international law and international relations. Subtle doctrinal predispositions will only frustrate objective interpretation and the experimentation necessary to the growth of the international system.

It is this conservative interpretational tendency that has confused analysis concerning the Iran-United States Claims Tribunal. Thus far, this analysis has rested primarily on intuition and analogy. These means of analysis carry

\footnotetext{
${ }^{108}$ Interestingly, in AMINOIL it reportedly was the state party, Kuwait, that argued for the arbitration to be governed by French law; AMINOIL argued for an anational process. Redfern, supra note 61 , at 77 . In this sense, it is Kuwait arguably that pressed for a more effective award. Id. at 86.

${ }^{109}$ For example, the U.S. Foreign Sovereign Immunities Act recognizes that immunity may be waived, 28 U.S.C. $\$ 1605(a)(1)$ (1982), and the House Report explaining that provision noted that " $[w]$ ith respect to implied waivers, the courts have found such waivers in cases where a foreign state has agreed to arbitration in another country." H.R. REP. No. 1487, 94th Cong., 2d Sess. 6 (1976), 1976 U.S. CODE CoNG. \& ADMIN. News 6604, 6617. See generally Fox, supra note 17; Oparil, Warver of Sovereign Immunity in the United States and Great Brilain by an Arbitration Agreement, 3 J. INT'L ARB. 61 (1986); Sullivan, Implicit Waiver of Sovereign Immunity by Consent to Arbitration: Territorial Scope and Procedural Limits, 18 TEx. INr'L L.J. 329 (1983).
} 
with them many doctrinal predispositions. What is needed, instead, is careful study of what Iran and the United States intended to accomplish in the Algiers Accords. Thus, this article now shifts from the exposition of a general theory to the examination of a specific case.

\section{The Legal System Supervising the Iran-U.S. Claims Tribunal}

One of the most innovative and intellectually satisfying aspects of the Algiers Accords is that they establish for the Iran-United States Claims Tribunal a rather complete internal world. There is little need for the parties to request assistance from powers external to the Tribunal. The UNCITRAL Arbitration Rules ${ }^{110}$ provide for an appointing authority to resolve disputes between the parties over the composition of the Tribunal. ${ }^{111}$ More importantly, the Algiers Accords established a fund, the Security Account, with a portion of the Iranian assets that the United States had frozen. With the Algerian Government acting as escrow agent for the Security Account pursuant to the Tribunal's instructions, the Security Account assures the availability of funds to satisfy most awards of the Tribunal. ${ }^{112}$

Nevertheless, to say that there is little need to refer to the world outside the Tribunal is not to say that there is none. Already, a British court has had to consider whether it should recognize an award of the Tribunal as res judicata. ${ }^{113}$ Moreover, the Security Account may satisfy only the claims of United States nationals, not awards in favor of Iranian nationals or Iranian governmental counterclaimants. ${ }^{114}$ Indeed, a current action in U.S. court seeks to enforce such a counterclaim award. ${ }^{115}$ In addition, if the Security Account were to become depleted, the unsatisfied beneficiaries might be required to seek enforcement of their awards elsewhere. ${ }^{116}$ Finally, a party

\footnotetext{
11" After 3 years of development involving all interested nations, the UNCITRAL Rules, supra note 26, were adopted by the United Nations Commission on International Trade Law (UNCITRAL) on Apr. 28, 1976, and recommended for use without further debate by the General Assembly on Dec. 15, 1976. See K. RAuH, Die Schieds- UNd SchlichtungsordNUNGEN DER UNCITRAL (1983); Sanders, Commentary on UNCITRAL Arbitration Rules, 2 Y.B. CoM. ARB. 172 (1977). Article III(2) of the Claims Settlement Declaration, supra note 1, provides that the Tribunal shall use the UNCITRAL Rules "except to the extent modified by the Parties or by the Tribunal." Set Aksen, The Iran-United States Claims Tribunal and the LNITRAL Arbetration Rules-an early comment, in THE ART OF ARBITRATION, supra note 57, at 1 .

iil Sit' UNCITRAL Rules, supra note 26, Arts. 6-14.

112 State claimants have achieved similar security in the past by holding on to frozen assets for possible satisfaction of judgments rendered in their favor. The United States, for example, held German assets in this way after World War I and ultimately used a portion of those assets to satisfy awards made by the U.S.-German Mixed Claims Commission in favor of U.S. nationals. Ste Borchard, The Setllement of War Claims Act of 1928, 22 AJIL 373 (1928); McHugh, Sitlement of War Claims Act of 1928, 14 A.B.A.J. 193 (1928).

"1' Mark Dallal v. Bank Mellat, supra note 11.

${ }^{11} S_{k \nless}$ General Declaration, supra note 1, para. 7 ("All funds in the Security Account are to be used for the sole purpose of the payments of . . . claims against Iran . . .").

15. Ministry of Defense v. Gould, Inc., supra note 12.

11" As stated in the brief for the United States as amicus curiae in Ministry of Defense v. Gould, Inc., 887 F.2d 1357 (9th Cir. 1989) [hereinafter Amicus Curiae Brief]:
} 
dissatisfied with an award may wish to challenge it and have it set aside. Thus, although the Tribunal is substantially less dependent upon the external legal world than many other forms of arbitration, that dependency remains significant.

Another factor in analyzing the Tribunal's relationship to the external legal world is the Tribunal's three primary jurisdictional grants. It must be asked whether the legal system supervising the arbitral process before the Tribunal is a function of the particular basis of jurisdiction. First, the Tribunal may hear "claims of nationals of the United States against Iran and claims of nationals of Iran against the United States" ${ }^{117}$ (claims of nationals). Second, the Tribunal has jurisdiction over "official claims of the United States and Iran against each other arising out of [certain] contractual arrangements between them" 118 (official claims). Third, the Tribunal may hear disputes between Iran and the United States concerning the interpretation or performance of any provision of the General Declaration ${ }^{119}$ or the interpretation or application of the Claims Settlement Declaration ${ }^{120}$ (interpretive disputes). The vast bulk of the disputes falls into the first category, claims of nationals. ${ }^{121}$ Moreover, the main point of contention between Iran and the United States, in scholarly commentary and in judicial clecisions, has been the legal system governing arbitrations involving claims of nationals. Iran at times has contended that these are interstate arbitrations. The United States, on the other hand, after some consideration, has taken the position that these are more akin to international commercial arbitrations, as they are governed by the legal system of the Netherlands and the resulting awards have Dutch nationality. Iran at other times has joined the United States in characterizing the awards as Dutch. Neither Iran nor the United States has expressed views on the legal system to be applied to the arbitrations involving official claims or interpretive disputes. Consequently, a substantial portion of the evidence regarding intent relates only to the first grant of jurisdiction. As will be seen, however, the analysis set forth below appears to be equally applicable to the official claims and interpretive disputes.

This analysis focuses on three issues: (1) the intention of the state parties to rest the arbitrations involving claims of nationals on the interstate process of diplomatic protection; (2) the intention of the state parties to have the

While to date these awards have been paid from the Security Account [and] [a]lthough the United States expects Iran to carry out its obligation to replenish the Security Account in the future, should Iran not do so, the vast majority of private claims before the Tribunal will be dependent on judicial enforcement of Tribunal Awards.

Id. at 7.

${ }^{117}$ Claims Settlement Declaration, supra note 1, Art. II(1).

${ }^{118}$ Id., Art. II(2).

${ }^{119}$ Id., Art. II(3); General Declaration, supra note 1, para. 17.

${ }^{120}$ Claims Settlement Declaration, supra note 1, Art. VI(4).

121 The Tribunal's docket is composed of approximately 3,761 claims of nationals, 78 official claims and 22 interpretive disputes. 
legal system of the Netherlands govern the validity of the arbitrations; and (3) the willingness and ability of the Netherlands to accommodate the desires of the United States and Iran.

\section{Claims of Nationals and Diplomatic Protection}

An important preliminary question is whether the arbitrations involving "claims of nationals" are based on claims raised by the nationals themselves or by their governments through the interstate mechanism of diplomatic protection. ${ }^{122}$ If these arbitrations are based on diplomatic protection, the long history of this practice would suggest that Iran and the United States intended that they be subject to review under the international legal system.

In the Dual Nationality case, decided in 1984, Iran asserted that U.S. nationals who also possessed Iranian nationality (hence the phrase "dual nationals") could not bring claims against Iran before the Tribunal. In support of this position, Iran argued that the arbitrations before the Tribunal were an instance of diplomatic protection. According to Iran, the extensive customary international practice on diplomatic protection, which in Iran's view weighed against the espousal of claims of dual nationals, informed the Algiers Accords. ${ }^{123}$ In its Memorial, Iran ${ }^{124}$ noted that Article

\footnotetext{
12: Diplomatic protection is, in the words of the Permanent Court of International Justice, a situation in public international law whereby, "in taking up the case of one of its nationals, by resorting to diplomatic action or international judicial proceedings on his behalf, a State is in reality asserting its own right, the right to ensure in the person of its nationals respect for the rules of international law." Panevezys-Saldutiskis Railway Case (Estonia v. Lithuania), 1939 PCIJ (ser. A/B) No. 76, at 16 (Judgment of Feb. 28). See also G. Leigh, Nationality and Diplumatic Protection, 20 INT'L \& COMP. L.Q. 453, 455 (1971).

${ }_{1233}$ Islamic Republic of Iran and United States (Case A18) (Dual Nationality), Dec. 32-A18FT (Lagergren, Holtzmann (CO), Kashani (DO), Riphagen (CO), Aldrich, Shafeiei (DO), Mangărd, Ansari (DO), \& Mosk (CO), arbs., Apr. 6, 1984), 5 IRAN-U.S. C.T.R. 251 (1984 I).

Citations to this award and those below include the names of the arbitrators who were members of the panel rendering the award. The Chairman is always listed first, with the other arbitrators following in alphabetical order. Parenthetically following each name is, as appropriate, a letter or letters reflecting the arbitrator's position vis-a-vis the Tribunal's award. These symbols are: C, concurring; D, dissenting; CS, concurring via statement by signature; DS, dissenting via statement by signature; $\mathrm{CO}$, concurring opinion; $\mathrm{DO}$, dissenting opinion; SO, separate opinion; and RS, refusal to sign. An indication of dissent or concurrence with a whole award does not necessarily indicate dissent or concurrence with the particular point being discussed in this study.

On dual nationals' claims before the Tribunal, see generally Mahoney, The Standing of Dual Natimuls Brfore the Iran-United States Claims Tribunal, 24 VA. J. INT'L L. 695 (1984); Note, Claint of Dual Vationals in the Modern Era: The Iran-United States Claims Tribunal, $83 \mathrm{MicH}$. L. Rev. 597 (1984); Leurent, Problèmes soulevés par les demandes des double nationaux devant le Trihunal des differends irano-américains, 74 ReVUE CRITIQUE DE DROIT INTERNATIONAL PRIVÉ [RCDIP] 273-99, 477-503 (1985); and Rigaux, L'Admissibilité des demandes introduites devant un tribunal international par les binationaux et la décision de l'Iran-United States Claims Tribunal sur cette question (paper presented in The Hague, May 29, 1984).

121 Memorial of the Islamic Republic of Iran in Case A18 (Oct. 21, 1983) [hereinafter Iranian A18 Memorial], reprinted in IRANIAN ASSETS LITIGATION REPORTER [hereinafter I.A.L.R.], Nov. 18, 1983, at 7,503.
} 
II(1) of the Claims Settlement Declaration provides that "an international arbitral tribunal (the Iran-United States Claims Tribunal) is hereby established."125 Although Iran recognized that the "fact that the Tribunal was created by international agreement does not necessarily . . . exclude its having been created in order to settle disputes of national law," it argued that the overall purpose of the Tribunal was to end disputes between the two states, that other jurisdictional categories clearly involved intergovernmental disputes, and that the two states (and not the private parties) had designated the arbitrators and were bearing the expense of the arbitration. ${ }^{126}$ The phrase "claims of nationals," in Iran's view, "serves solely to identify" a class of international claims and "does not prejudge the nature of the claims nor the law which should be applied to them."127 Iran concluded that it is clear from

the structure, the spirit and the terms of the Declarations, that this tribunal is truly international since it is called upon to settle a dispute between States, arising from the treatment by one of them of the nationals of the other, the solution to which must be found in public international law and not disputes between one State and nationals of the other, which could be resolved by the application of private international law. ${ }^{128}$

Given the international origin of the Tribunal and the prevailing view that individuals are not subjects of international law, "[a]ll this confirms that the provisions concerning the resolution of disputes reflect classical requirements of diplomatic protection."129

The United States rebutted this position, arguing that it ignored the most important evidence-what the parties had agreed to in the Accords:

The Iranian position seems to depend on a combined historical and theoretical analysis of what international tribunals should be. The theory is not derived from the facts of how this Tribunal is constructed. The facts are formed to fit the theory. If the facts don't fit the theory, Iran says that they don't really contradict it, however important the facts are. ${ }^{130}$

The Full Tribunal in its decision in the Dual Nationality case observed that "most disputes [before it] involve a private party on one side and a Government or Government-controlled entity on the other." The Tribunal went on to hold that "the object and purpose of the Algiers Declarations was to resolve a crisis in relations between Iran and the United States, not to extend diplomatic protection in the normal sense."131

\footnotetext{
${ }^{125} \mathrm{Id}$. at $16-17$ (emphasis added).

${ }^{126} \mathrm{Id}$. At least in the United States, a portion of the costs of the Tribunal is borne by the successful private claimants via a user fee placed by the U.S. Government on the amounts awarded to such claimants. See United States v. Sperry Corp. 58 U.S.L.W. 4018 (U.S. Nov. 28, 1989). See also the summary of the earlier opinion of the court of appeals in $83 \mathrm{AJIL} 86$ (1989).

${ }^{127}$ Iranian A18 Memorial, supra note 124, at 25-26.

${ }^{128} \mathrm{Id}$. at 18.

${ }^{130} 1$ U.S. Transcript of the Case A18 Hearing 140 (Nov. 9, 1983).

${ }^{131}$ Case A18 (Dual Nationality), supra note 123, at 18-19, 5 IRAN-U.S. C.T.R. at 261.
} 
Despite this decision of the Full Tribunal, Iran has maintained its view that the claims of nationals are indeed the claims of the government of those nationals. ${ }^{132}$ In its 1987 decision in Case A21, the Full Tribunal reiterated that "Tribunal awards uniformly recognize that no espousal of claims by the United States is involved in the cases before it." ${ }^{133}$ Nonetheless, the Iranian arbitrators continue to file lengthy opinions arguing that the claims of nationals are raised through espousal. ${ }^{134}$

Examination of the Accords supports the Full Tribunal's view that the Tribunal is international in origin but has as its primary purpose the resolution of claims between a private party and a state. The notion of diplomatic protection has structural implications simply not present in the case of the Tribunal.

Classically, for a state to espouse a claim on the basis of diplomatic protection, its national must have exhausted the remedies provided locally by the allegedly offending state. ${ }^{135}$ The exhaustion of remedies without redress constitutes a part of the complicity of the second state in the injury to the national of the first state. However, the customary international law requirement that a claimant exhaust local remedies is not without limits. ${ }^{136}$ The situation within Iran and between the two countries, for example, affords good reason to conclude that the requirement would have been waived by the Tribunal even if the claims had been presented on the basis of diplomatic protection. ${ }^{137}$ Yet the Tribunal has not waived the requirement

\footnotetext{
${ }_{1.2} S_{t}, r . g .$, Memorial of the Islamic Republic of Iran, Case A21, at 15 (May 15, 1986) (interpretive dispute dealing with the duty of the state parties to execute judgments rendered against their nationals), reprinted in I.A.L.R., July 25, 1986, at 12,682, 12,693 ("All this confirms that the provisions concerning the resolution of disputes reflect classical requirements of diplomatic protection. . ."). See also A Recent Review of the Cases at the Hague Tribunal, Kayhan [Iranian newspaper], June 13, 1984 (U.S. Dep't of State trans.) (statement of an Iranian official after the decision in Dual Nationality that "[w]e believe . . . that The Hague arbitration is an international arbitration and the Netherlands' Government has no right to interfere with it").

${ }^{138}$ Islamic Republic of Iran and United States (State Party Responsibility for Awards Rendered Against its Nationals), Dec. 62-A21-FT, para. 12 (Böckstiegel, Holtzmann, Mostafavi (SO), Briner, Aldrich, Bahrami-Ahmadi (SO), Virally, Salans, Ansari (SO), arbs., May 4, 1987), I4 IR.N-U.S. C.T.R. 324, 330 (1987 I).

${ }^{134}$ St $t, t_{\text {. }}$., Concurring/Dissenting Opinion of Assadollah Noori (June 3, 1988) to Leonard \& Mavis Daley and Islamic Republic of Iran, AWD 360-10514-1 (Böckstiegel, Holtzmann \& Noori (CO/DO), arbs., Apr. 20, 1988); Separate Opinion of Seyed Khalil Khalilian (Feb. 23, 1988) to Lord Corp. and Iran Helicopter Support \& Renewal Co., AWD 346-10973-2 (Briner, Aldrich \& Khalilian (SO), arbs., Jan. 29, 1988).

${ }^{135} S_{\ell,}$ Claim of Finnish Shipowners (Fin. v. Gt. Brit.), 3 R. Inț'l Arb. Awards 1479 (1934) (Bagge, sole arb.).

${ }^{13{ }^{*}} S_{k^{\prime}}$ Interhandel Case (Preliminary Objections) (Switz. v. U.S.), 1959 ICJ REP. 6 (Judgment of Mar. 21); American Int'l Group v. Islamic Republic of Iran, 493 F.Supp. 522, 525 (D.D.C. 1980) ("It is well settled in international law that where local remedies would be ineffective or meaningless or would not meet the international standard of minimum justice, the alien need not subject himself, in the first instance, to the local courts or administrative tribunals").

${ }^{137}$ Se' Rexnord and Islamic Republic of Iran, AWD 21-132-3, at 8-9 (Mangård, Mosk \& Sani (RS), arbs., Jan. 10, I983), 2 IRAN-U.S. C.T.R. 6 (1983 I); American Int'l Group and Islanic Republic of Iran, AWD 93-2-3, at 9 (Mangård, Ansari (RS) \& Mosk (CO), arbs., Dec.
} 
but, instead, has simply held it not to be applicable to the claims of nationals before the Tribunal. ${ }^{138}$

More important than exhaustion of local remedies are aspects of the Accords that indicate in various ways that these claims belong to the national and not to the state, as they would if they were based on diplomatic protection. ${ }^{139}$ Article II(1) of the Claims Settlement Declaration does not provide, as might be expected for diplomatic protection, that the Tribunal may decide claims of the United States or Iran brought "on behalf of the interests of its nationals" or "on the basis of injury to its nationals." Rather, the provision provides jurisdiction over the "claims of nationals of the United States and of Iran."

That the claim belongs to the national is substantiated by the fact that the Claims Settlement Declaration provides that the nationals themselves shall present their claims to the Tribunal. ${ }^{140}$ Not only have claims of U.S. na-

19, 1983), 4 IRAN-U.S. C.T.R. 96 (1983 III); and Time and Islamic Republic of Iran, AWD 139-166-2, at 4 (Riphagen, Aldrich \& Shafeiei (DS), arbs., June 29, 1984), 7 IRAN-U.S. C.T.R. 8 (1984 III). But see Dissenting Opinion of M. Kashani (Sept. 13, 1984) to Starrett Housing and Islamic Republic of Iran, ITL 32-24-1, at 55 (Dec. 19, 1983), 7 IRAN-U.S. C.T.R., supra, at 119. Cf. Schwebel, Some Aspects of International Law in Arbitration Betu'en States and Aliens, in 1986 Private INVESTORS ABroad-Problems AND SOlutions In INTERNATIONAL Business 12-1, 12-8 (J. Moss ed.).

${ }^{138}$ See, e.g., Amoco Int'l Finance Corp. and Islamic Republic of Iran, AWD 310-53-5, para. 21 (Virally, Brower (CO) \& Ansari (C/D), arbs., July 14, 1987), 15 IRAN-U.S. C.T.R. 189, 197 (1987 II).

${ }^{139}$ See Leigh, supra note 122 , at 455.

${ }^{140}$ A supplemental clause provides that when the claim is less than $\$ 250,000$, the claim may also be presented by the government of that national. Claims Settlement Declaration, supra note 1 , Art. III(3). In the event, the claims of U.S. nationals for less than $\$ 250,000$ were filed by the United States; the typical caption for the claimant read, "The United States of America, on behalf and for the benefit of the [name of private claimant]." The Tribunal, in the spring of 1986 on its own initiative, changed the caption of the claims for less than $\$ 250,000$ to read, "[name of private claimant], a claim of less than U.S. $\$ 250,000$ presented by the United States of America." See, e.g., Picker Int'l Corp. and Islamic Republic of Iran, AWD 229-10173-3 (Virally, Brower \& Ansari, arbs., May 1, 1986). The Agent for Iran filed Requests for Correction of Award asking that the original caption be reinstated. The Tribunal denied these requests, stating that Article III(3) of the Claims Settlement Declaration indicates that the claim "remains the claim of the national and not of the Government of such national . . . the Government of the national owning such claim merely presents the claim . . . " See Koehler and Islamic Republic of Iran, Dec. 43-11713-1 (Böckstiegel, Holtzmann \&e Mostafavi (DS), arbs., July 3, 1986), 11 IRAN-U.S. C.T.R. 285 (1986 I). See also Trustees of Columbia Univ. and Islamic Republic of Iran, Dec. 42-10517-1 (Böckstiegel, Holtzmann \& Mostafavi (DS), arbs., July 3, 1986), 11 IRAN-U.S. C.T.R., supra, at 283; Baygell and Islamic Republic of Iran, Dec. 46-10212-2 (Briner, Aldrich \& Bahrami-Ahmadi (DS), arbs., Aug. 7, 1986), 11 IRAN-U.S. C.T.R., supra, at 300 . Since that time, Iranian arbitrators have filed separate opinions arguing that the claims for less than $\$ 250,000$ are espoused by the United States, and occasionally on their separate opinions have altered the case caption to read "[name of private claimant]" presented by THE UNITED STATES OF AMERICA in protection of its national." See opinions cited supra note 134.

As a precautionary measure, the United States also filed a claim for more than $\$ 250,000$ for all of the claimants potentially holding claims for less than $\$ 250,000$ (Case 86 ). The Statement of Claim in Case 86 was presented "in continuance of the exercise of diplomatic protection of its nationals, acting as parens patriae, trustee, guardian and representative on their behalf." 
tionals been filed and argued by those very nationals, but it is also the national that decides whether to withdraw or to accept settlement. Indeed, the Agent for Iran reportedly supported the primacy of the national, arguing that the U.S. Agent may not speak at hearings on the claims of nationals because the United States is not a party to such proceedings. ${ }^{141}$

An example of the importance given to the owner of the claim can be found in the American-Turkish Claims Settlement of 1937, in which numerous claims were rejected almost immediately because they were filed directly with the commission by private counsel representing the nationals. The Agreement of December 24, 1923, between the United States and Turkey establishing the commission provided for governmental espousal of claims. The commission took the position that the direct presentation of claims by nationals was incompatible with the idea of diplomatic protection: "It would, of course, be monstrous to suggest that a government would through some subterfuge pretend to support a claim without having any knowledge of what, if anything, had in some way come before the Commission." 142

Just as importantly, the Security Account satisfies Tribunal awards directly to the benefit of the national who presents the claim and is the named party, and not to the benefit of the government of that national. ${ }^{143}$ Indeed, the U.S. Government has been the subject of extensive litigation in the United States because of its efforts to recoup a part of awards to its nationals to cover the administrative expenses of the Tribunal. ${ }^{144}$

A more subtle indicator of the nature of the arbitrations, suggested by David Lloyd Jones, is whether the duties placed on the respondent government flow to the claimant private party or to the private party's state. ${ }^{145}$

This claim, often called the "blanket claim," has not been the subject of any proceedings. "The primary purpose of the filing was to provide a convenient mechanism for dealing with the claims if a lump sum settlement were reached with Iran." Response of the United States, Case A21, at 11 (September 1986), reprinted in Mealey's Litigation ReP.-IRANIAN Claims [hereinafter MEALEY's], Oct. 3, 1986, at 4913, 4919.

${ }^{141} S_{t}$, e.g.. Letter from A. Rovine to G. Lagergren (May 28, 1982) ("the Agent of the Islamic Republic of Iran, questioned my right to speak at the conference and stated that my attendance was at the "courtesy' of his Government"). Indeed, the Tribunal in its awards in such arbitrations lists the U.S. representatives as merely "Also Present."

Likewise, Iran has reportedly characterized as "unwarranted and unjustified" the filing of comments by the U.S. Agent on proposed settlements of such arbitrations. Letter from M. Eshragh to M. Virally (Jan. 9, 1986), cited in Response of the United States, supra note 140, at 21, reprinted in MEALEY's at 4924.

142 F. K. Nielsen \& J. Maktos, American-Turkish Claims Settlement 6 (U.S. Government Printing Office, 1937). See also $6 \mathrm{~J}$. B. MOORE, A Digest OF INTERnational LaW 616 (1906).

${ }^{143}$ Similarly, it is against the national, and not the government of that national, that the Tribunal's Rules require entry of counterclaims and awards of costs. See Introduction and Definitions, para. 3c, Final Tribunal Rules of Procedure, May 3, 1983, reprinted in 2 IRAN-U.S. C.T.R. 405, 406 (1983 I); Rules, Arts. 32 and 40, id. at 434 and 440.

${ }^{144}$ Ser Sperry Corp., supra note 126.

${ }^{145} \mathrm{Jones}$, The Iran-United States Claims Tribunal: Private Rights and State Responsibility, 24 VA. J. INT'L L. 259, 261 (1984) (footnotes omitted). Jones asks: 
Speaking in 1983, Jones speculated as to what the Tribunal's response would be to the many claims of nationals based on, for example, the Treaty of Amity between the United States and Iran, in which the duties accepted by each state run to the other. What Jones overlooked, however, is that the Tribunal was intended primarily as a substitute forum for private claimants in U.S. courts. The decision in the Dual Nationality case confirms this view. ${ }^{146}$ Significantly, United States law provides private parties certain rights under international law otherwise belonging to the state. International law created by treaty is a part of the national law of both Iran ${ }^{147}$ and the United States. ${ }^{148}$ But "[i]t is only when a treaty is self-executing, when it prescribes rules by which private rights may be determined, that it may be relied upon for the enforcement of such rights." 149 Under U.S. law, the property protection provisions of treaties, such as the Treaty of Amity, have consistently been regarded as self-executing and granting a private right of enforcement. ${ }^{150}$ Indeed, this right was recognized by U.S. courts in relation to the Treaty of Amity between the United States and Iran. ${ }^{151}$ Richard M. Mosk, an arbitrator with the Tribunal, concluded that if one took into account the existence of these private rights and the impediment they presented to the state parties' conclusion of the Accords, "[i]t does not seem logical that by shifting such disputes to arbitration before this Tribunal the parties to the Algiers Declarations intended to eliminate the substantive

Is the Tribunal a private arbitral tribunal created to resolve private law disputes arising under different systems of law and to hear private law claims against Iran and the United States, or is it an international or interstate tribunal charged with the task of ruling on the responsibility of the respondent State under public international law for the conduct which constitutes the subject matter of the claims? If the former is the case, the Tribunal would be required to rule on infringements of private law rights arising in municipal legal systems . . . On this view, the United States and Iran may be regarded as having referred to a private transnational arbitral tribunal questions of private law which might in other circumstances be justiciable before domestic courts. If the latter is the case, the competence of the Tribunal lies in respect of such claims as are true international claims founded on an alleged breach of international law. On this view, the Tribunal is an international or interstate tribunal dealing with the rights and duties of States under public international law in relation to their activities on the international plane, and is primarily concerned with an exercise in diplomatic protection on behalf of the United States.

146 The Full Tribunal held in the Dual Nationality case, supra note 123, at 19,5 IRAN-U.S. C.T.R. at 261-62:

It seems clear that a major obstacle to the resolution of that crisis was the existence of much litigation in the courts of the United States brought against Iran by citizens of the United States, often involving judicial attachments of Iranian assets. In order to overcome that obstacle and permit the return of these assets and the termination of that litigation, a new substitute forum-this Tribunal-was established.

See also Esphahanian and Bank Tejarat, AWD 31-159-2 (Bellet, Aldrich \& Sliafeiei (RS/DO), arbs., Mar. 29, 1983), 2 IRAN-U.S. C.T.R. 157 (1983 I) ("the Tribunal has been substituted for the national courts of both countries"; $i d$. at 166$)$.

147 IRANian Civil Code Art. $9 . \quad 148$ U.S. Const. Art. VI, cl. 2.

${ }^{149}$ Dreyfus v. Von Finck, 534 F.2d 24, 30 (2d Cir. 1976).

${ }^{150}$ See Asakura v. Seattle, 265 U.S. 332 (1924). See also R. WiLson, UNITI:D STATES CoMMERCIAL TREATIES AND INTERNATIONAL LAW (1960).

${ }^{151}$ American Int'l Group v. Islamic Republic of Iran, 493 F.Supp. 522, 525 (D.D.C. 1980). 
rights of the parties to base a claim on a Treaty of Amity violation or otherwise to invoke that Treaty as applicable law."152

Thus, the Tribunal, although international in origin, has before it both intergovernmental claims and claims by nationals of one state party against the government of the other state party. But their choice not to adopt the process of diplomatic protection does not necessarily mean that the state parties intended that the legal system of the place of arbitration rather than the international legal system should govern these arbitrations.

\section{The Intent of Iran and the United States}

The intent of a state in any given circumstance can be elusive. In the following analysis, I take the observational standpoint of a tribunal or court and attempt to find the objectively determinable intent of the United States and Iran. In a few instances, I note what sources have told me that U.S. government officials intended or could not have intended. In general, however, the analysis rests upon the agreements between, and the practice of, the two states.

The objectively determinable intent of the state parties initially should be sought in the Algiers Accords themselves. This inquiry should proceed in accordance with the interpretive provisions of the Vienna Convention on the Law of Treaties, in particular, its Article 31(1), which states that "[a] treaty shall be interpreted in good faith in accordance with the ordinary meaning to be given to the terms of the treaty in their context and in the light of its object and purpose."153

The Accords contain no express statement on the lex arbitri intended by the parties, but three provisions have been referred to by one or the other of the state parties or by commentators. First, Article II(1) of the Claims Settlement Declaration refers to the Tribunal as an "international arbitral

\footnotetext{
15: Concurring Opinion of Richard M. Mosk at 8 (Dec. 30, 1983) to American Int'l Group and Islamic Republic of Iran, supra note 137, 4 IRAN-U.S. C.T.R. at 111. See also Separate Opinion of Charles N. Brower at 5 (Mar. 27, 1986) to SEDCO and Islamic Republic of Iran, ITL 59-129-3 (Mangård, Brower (SO) \& Ansari (D), arbs., Mar. 27, 1986), 10 IRAN-U.S. C.T.R. 180,189 (1986 I).

${ }^{153}$ Vienna Convention on the Law of Treaties, Art. 31(1), opened for signature May 23, 1969 , 1155 UNTS 331 , reprinted in 8 ILM 679 (1969) (entered into force Jan. 27, 1980).

Iran and the United States on several occasions declared that the Vienna Convention, although not directly applicable, governs interpretation of the Accords. See, e.g., Islamic Republic of Iran and United States (Dual Nationality), supra note 123, at 14-15, 5 IRAN-U.S. C.T.R. at 259. The Tribunal has also consistently applied the Vienna Convention. See, e.g., United States and Islamic Republic of Iran (Security Account Issues), Dec. 12-A1-FT, at 3 and 5 (Aug. 3, 1982), 1 IRAN-U.S. C.T.R. 189, 190 (1981-82); Islamic Republic of Iran and United States (Dual Nationality), supra note 123; United States and Islamic Republic of Iran (Standby Letters of Credit), AWD 108-A16/582/591-FT, at 15 (Jan. 25, 1984), 5 IRAN-U.S. C.T.R. 57 (1984 I); and United States and Islamic Republic of Iran (Iranian Bank Claims), Dec. 37-AI7-FT, at 16 (June 18, 1985), 8 IRAN-U.S. C.T.R. 189 (1985 I). Notwithstanding the views of the state parties, the interpretation provisions of the Vienna Convention would likely be applicable since they are generally regarded "as declaratory of existing law." Jiménez de Aréchaga, Intmattonal Law in the Past Third of a Century, I59 ReCueIL DEs Cours 1, 42 (1978 I).
} 
tribunal." Second, Article VI(1) of the same Declaration states that the "seat of the Tribunal shall be The Hague" or any other place agreed to by the state parties. Finally, Article III(2) provides that "the Tribunal shall conduct its business in accordance with the arbitration rules of the United Nations Commission on International Trade Law (UNCITRAL) except to the extent modified by the Parties or by the Tribunal."

The fact that the Tribunal was established by treaty and is thus an "international arbitral tribunal" has greatly influenced the commentators who have challenged review of the Tribunal's awards by Dutch courts. Indeed, Lake and Dana, in pointing to this language, are stressing the same phrase that Iran relied upon in support of its argument on diplomatic protection. ${ }^{154}$ As in that argument, this approach confuses origin with purpose. In essence, these commentators find it significant, if not dispositive, that the state parties used a treaty to establish the Tribunal, but they suggest no alternative means by which the state parties might have done so. There appears to be no reason that an arbitral institution of private origin might not hear an interstate arbitration or that an institution of public origin might not hear international commercial arbitrations. Thus, the simple description of the Tribunal as an "international arbitral tribunal" provides little evidence of intent. As we have seen, this phrase did not mean that the parcies intended that the claims of nationals be presented on the basis of diplomatic protection; rather, it characterizes the origin of the Tribunal. It also does not necessarily describe the nature of the disputes the institution was intended to adjudicate.

Likewise, locating the Tribunal in The Hague is not by itself a significant piece of evidence as to intent. Although the legal system of the place of arbitration is the lex arbitri for international commercial arbitration, the place of arbitration is commonly indicated in purely interstate arbitration as well, without any intent to subordinate the process to the local legal system.

The choice of the UNCITRAL Rules, however, is very significant. Other tribunals have regarded the parties' choice of procedural rules as an indication of intent. ${ }^{155}$ The primary alternatives available to the drafters of the Accords were the United Nations Draft Convention on Arbitral Procedure and the UNCITRAL Rules of Arbitral Procedure. The Draft Convention was designed for use in interstate arbitration, while the UNCITRAL Rules were intended for use in international commercial arbitration. In the $A R A M C O$ and TOPCO arbitrations, the only two arbitrations between a private party and a state in which the lex arbitri was found to be international

154 They wrote:

The Tribunal is a very different institution from the tribunals to which national arbitration laws such as the Dutch Code typically apply. It is not an ad hoc entity called into life by a commercial contract to resolve disputes under the contract, but an "International Arbitral Tribunal," established by two sovereign states through an international agreement that has the status of a treaty under international law.

Lake \& Dana, supra note 15, at 773 (footnotes omitted).

${ }^{155}$ See, e.g., text at note 84 supra. 
law and not the legal system of the place of arbitration, the arbitrators employed the UN Draft Convention on Arbitral Procedure. ${ }^{156}$

The UNCITRAL Rules chosen by the drafters of the Accords demonstrate both by their general structure and by Article 1(2) specifically that it can be "taken for granted that there is an applicable national law." provides that " $[\mathrm{t}]$ hese Rules shall govern the arbitration except that where any of the Rules is in conflict with a provision of the law applicable to the arbitration from which the parties cannot derogate, that provision shall prevail." Thus, these internal rules of arbitration through Article 1(2) automatically adjust to the nonderogable provisions of the governing municipal arbitration law. Indeed, Article 1(2) assumes that a governing municipal arbitration law exists. ${ }^{158}$ In this sense, the presumed intent of parties adopting the UNCITRAL Rules calls for municipal review as clearly as if the choice instead had been the American Arbitration Association Rules or the ICC Rules. ${ }^{159}$ However, the presumed intent in the case of the Accords is merely presumptive because the Accords envisioned that their implementation might require modification of the Rules by the state parties or the Tribunal..$^{100}$

Interpretation of the Accords should also take into account that they were drafted in haste and that some clauses may not be the product of full deliberation. ${ }^{161}$ To "confirm the meaning resulting from the application of

\footnotetext{
${ }^{1565}$ Both ARAMCO and TOPCO were decided prior to the adoption of the UNCITRAL Rules. Other private arbitration rules, however, were available at the time.

${ }^{157}$ Böckstiegel, The Relevance of National Arbitration Law for Arbitrators under the UNCITRAL Rules, I J. INT'L ARB. 223, 230 (1984). See also Sanders, supra note 110, at 179; AAA Report, supra note 59, at 5; I. DORE, ARBITRATION AND CONCILIATION UNDER THE UNCITRAL Rulfas: A Textual ANAlysis 45-46 (1986).

${ }^{15 x}$ The entire UNCITRAL project was directed at developing rules of procedure for international commercial arbitration that would be acceptable worldwide and, in particular, to the developing world. See I. DORE, supra note 157, at 44; Introduction to Commentary on Preliminary Draft of the UNCITRAL Rules, UN Doc. A/CN.9/97 (1975). Originally, the drafters spread references throughout the Rules to the possible overriding effect of the governing legal system. At the ninth session, however:
}

Committee [II] considered the relationship between the Rules and the provisions of the national law applicable to the arbitration. It was agreed that the inclusion only in selected articles of the Rules of a proviso that the particular article was subject to the national law applicable to the arbitration would give rise to arguments a contrario in respect of other articles which did not set forth such a proviso. The Committee therefore decided to add to article 1 a general reference to the effect that all provisions in these Rules were subject to the national law applicable to the arbitration.

Report of Committee II, Ninth Session, UN Doc. A/CN.9/IX/CRP.1, para. 12 (1976).

${ }^{154}$ S'e supra text at note 109 . $\quad{ }^{160}$ Hardenberg, supra note 13 , at 338.

${ }^{151}$ As noted by Richard Lillich, "the Claims Settlement Agreement establishing the Tribunal was cobbled together in haste and confusion." Lillich, supra note 2, at vii. Indeed, Roberts B. Owen, a principal U.S. negotiator, later wrote that "although the initial draft of the claims settlement declaration [by the United States] was some twenty-five pages long . . . , it was ultimately revised down to about three-and-a-half pages-surely one of the most concise legal documents of its kind ever written." Owen, The Final Negotiation and Release in Algiers, in AMERICAN Hostages IN IRAN 297, 312 (P. Kreisberg ed. 1986). 
Article 31 " and allow for the limitations inherent in textual interpretation, the Vienna Convention directs us to the preparatory work of the Accords. Unfortunately, little is known about the negotiating process. Several sources have indicated to me that more than a few of the American negotiators were unfamiliar with the idea of a lex arbitri and did not appreciate that the choice of the UNCITRAL Rules would accord supervisory jurisdiction to the legal system of the Netherlands. Indeed, one must remember that the UNCITRAL Rules were still quite new at the time the Accords were drafted and their UN origin might mistakenly lead one to conclude that they were designed for interstate arbitration rather than private international arbitration. ${ }^{162}$ On the other hand, several of the U.S. negotiators had come to the Department of State from private practice and were familiar with international commercial arbitration. The publicly available information on the negotiations indicates that some of the negotiators were familiar with the different processes and confirms at least the willingness of the United States to agree to a private, as well as a public, international arbitral process. In particular, such familiarity and willingness is apparent in the second U.S. negotiating response, given on December 3,1980, when the United States, in referring to the settlement of claims of its nationals, indicated its agreement "that such arbitration may be conducted, at Iran's election, by and under rules of the International Chamber of Commerce or the World Bank's International Center for the Settlement of Investment Disputes" (emphasis added).

Furthermore, the "object and purpose" of the Accords and "surrounding circumstances" also support a private characterization. In part I, I concluded that the trend toward regarding arbitrations between a private party and a state as private reflects the perception that in contract negotiations the private party's need for enforceability of the award often outweighs the state's interest in not waiving whatever immunity it has. The Accords, it is true, did not result from commercial negotiations, but rather memorialize diplomatic efforts to end a crisis in relations between the two countries. For this reason, one may not assume that the state parties were motivated by concerns identical to those of parties contemplating a commercial relationship. Nevertheless, the creation of the Security Account and Article IV(3) of the Claims Settlement Declaration are striking evidence of the importance attached to enforceability. ${ }^{163}$ Given the poor, if not hostile, relations be-

\footnotetext{
162 Consider, for example, the following somewhat ambiguous statement by Warren Christopher, chief U.S. negotiator of the Accords: "The settlement itself was simplified because a reliable body of arbitration law already existed in the United Nations system and could be lifted by reference into the agreement." Christopher, Introduction, in AmERICAN HosTaGeS IN IRAN, supra note 161 , at 1, 10-11.

${ }^{163}$ Article IV(3) provides: "Any award which the Tribunal may render against either government shall be enforceable against such government in the courts of any nation in accordance with its laws." Claims Settlement Declaration, supra note 1. Moreover, as Roberts Owen noted:
}

Although the release of the hostages was far and away the top priority of the U.S. government, we also wanted to avoid, if we possibly could, leaving our claimants without a 
tween the two countries, the U.S. concern about enforceability was not illusory. Thus, one probable objective of the United States in negotiating the Accords was to ensure the maximum enforceability of awards. Although the creation of the Security Account went far to satisfy this objective, it arguably is further satisfied by a private, rather than a public, characterization of the arbitrations involving nationals. Moreover, Iran may not have regarded a municipal lex arbitri as "an infringement of the prerogatives of the State which is a Party to the arbitration,"164 since Iran at that time was the defendant in hundreds of lawsuits in the United States. ${ }^{165}$ On the other hand, Iran's negotiating position, based on its control over 52 American nationals, was not weak. Indeed, the press of negotiations and the desire to avoid possibly contentious subsidiary issues may explain why the general approach of the UNCITRAL Rules was agreed to with the caveat that the parties or the Tribunal could modify those Rules at a later date.

The Vienna Convention also provides that parties may resort to "any subsequent practice in the application of the treaty which establishes the agreement of the parties regarding its interpretation." 166 This rule of interpretation is particularly appropriate when, as here, it was anticipated that subsequent changes might be made.

After signing the Accords, the state parties closely examined the provisions to which they had agreed and began developing their positions with regard to possible changes. ${ }^{167}$ The U.S. State Department recognized, for example, that the provision in the UNCITRAL Rules that the proceedings and resulting awards be kept confidential ${ }^{168}$ would hamper dissemination of the Tribunal's developing jurisprudence to other parties. ${ }^{169}$

A key concern was Article VI of the Claims Settlement Declaration, which provides for the seat of the Tribunal to be in The Hague "or any other place agreed by Iran and the United States." A debate commenced in the United States as to whether London might be more suitable. ${ }^{170}$ Various U.S. officials wondered whether it was in the best interests of the United States and

remedy, and a remedy could be arranged only if Iran could be persuaded, through negotiation, to join in a responsible arrangement for adjudicating the claims. Indeed, for the U.S. government to have abandoned the claimants in the context of the hostage crisis might well have been regarded as a payment of ransom for the hostages' release . . . .

Owen, supra note 161 , at 301 .

Jis ARAMCO, 27 ILR at 156.

${ }^{165} S^{\prime}{ }^{\prime}$ Hertz, The Hostage Crisis and Domestic Litigation: An Overview, in IRAN-UNITEd STATes TRIBUNAL, supra note 1 , at 136.

Iran apparently considered itself in danger of losing such cases, although the U.S. negotiators were aware that the U.S. plaintiffs' actions were vulnerable ultimately to claims of immunity by Iran. Set Owen, supra note 161, at 303-04.

tin Vienna Convention on the Law of Treaties, supra note 153, Art. 31(3)(b).

${ }^{167}$ Ste Iran-United States Litigation, Remarks of Arthur M. Rovine, 77 ASIL Proc. 3 (1983).

${ }^{16 x}$ UNCITRAL Rules, supra note 26, Art. 32(5).

${ }^{1 n 9} S_{t}$, e.g., Carter, Iran-United States Claims Tribunal: Observations on the First Year, 29 UCLA L. REV. 1076 (1982).

${ }^{177 "} S_{t e}, t . g .$, Symposium on the Settlement with Iran, 13 LAw. AM. 1, 46 (1981). Indeed, during the negotiation of the Accords, "the United States was inclined to favor London as the site of the proposed international tribunal, [but] the Algerians urged [the United States] to suggest 
U.S. nationals for the arbitral process to be governed by the Dutch legal system or by the English legal system, or whether the arbitrations should be subject to a municipal legal system at all. ${ }^{171}$ By the time the Agents of the two Governments and the party-appointed arbitrators first met in The Hague in May 1981, the debate within the United States apparently had ended in the belief that the arbitrations should be governed by the Dutch legal system. That this alternative was preferred at that time by the United States is reflected in the fact that it did not seek to change the situation by pursuing modifications in the UNCITRAL Rules. ${ }^{172}$ The clearest expression of this position can be found in the U.S. amicus curiae brief of July 1988 in Ministry of Defense of the Islamic Republic of Iran $v$. Gould, Inc.: "Tribunal awards appear to be valid and enforceable under Dutch law and therefore may be considered Dutch awards."173

Four events show that Iran also considered the arbitral process to be governed by the Dutch legal system from 1981 until 1984; that Iran reversed this position from 1984 to 1987 when it no longer appeared to be in Iran's interest; and that since 1987 Iran has taken inconsistent positions on the issue.

The decision not to modify Article 1(2) of the UNCITRAL Rules. The parties' choice of the UNCITRAL Rules in the Algiers Accords indicates a common intent that the arbitral process be subject to review by the Dutch courts. The significance of this choice is confirmed by the fact that neither the parties nor the Tribunal exercised their power to modify the approach of the Rules. The Tribunal was formally established in July 1981, and its Rules of Procedure adopted in March 1982. ${ }^{174}$ During this 9-month period, the Full Tri-

The Hague on the theory that it would be somewhat more palatable to the Iranians." Owen, supra note 161 , at 313 .

${ }^{171}$ At a symposium at the University of Miami Law School on Apr. 14, 1981, Mark Feldman, a lawyer with the U.S. State Department during the negotiation of the Accords, discussed the internal debate in the Department over these concerns and stated his personal preference for a process in which national courts would not interfere:

We are at a stage which raises a very complicated question concerning the law applicable to the proceeding. . . . It is a subtle and difficult thing. We are struggling with it right now. . - One of the things we will have to try and decide is how to keep the courts of the Netherlands or of England out of these cases.

Symposium, supra note 170 , at 38 .

172 Indeed, the statement of Mark Feldman at a second conference held on June 16-18, 1981, reflects this internal consensus:

At first blush, one might suppose that this arbitration is governed only by international law and that local law is irrelevant . . . After careful review of the conflicting literature on this subject and the characteristics of this proceeding, the State Department decided that prudence requires that the United States act on the assumption that proceedings conducted in the Netherlands will be governed by Dutch law . . . .

Feldman, Implementation of the Iranian Claims Setllement Agreement-Slatus, Issu's and Lessons: View from Government's Perspective, in 1981 Private INVESTORS ABroAD-Problems AND Solutions in INTERnational Business 75, 97-98 (J. Moss ed.).

${ }^{173}$ See Amicus Curiae Brief, supra note 116 , at 39.

${ }^{174}$ Provisionally adopted Mar. 10, 1982; permanently adopted May 3, 1983. See note 143 supra. 
bunal devoted a substantial portion of its time to considering modifications in the UNCITRAL Rules in light of its own concerns and the comments of the state parties. ${ }^{175}$ The retention of Article 1(2) in its original form was intentional. It signifies that the Dutch legal system should govern the arbitrations. Indeed, the addition by the Tribunal of Article 1(3), discussed more fully below, only increased the likelihood that Dutch courts could review the awards. ${ }^{176}$ Moreover, the Tribunal did not alter, and subsequently has complied with, Article $32(7)$ of the UNCITRAL Rules, which requires the Tribunal to register its awards in accordance with "the arbitration law of the country where the award is made." 177 There is no indication that either the United States or Iran objected to these actions. Indeed, the subsequent events, described below, suggest that they concurred in them. Even if one of the countries had objected, their agreement in the Accords to authorize the Tribunal to modify the Rules over the objection of one of them would have bound the objecting party.

The tripartite agreement. At the inception of the Tribunal's work, the state parties tended to seek written agreements on broad issues not settled by the Accords. One such effort, begun in May 1981, was the drafting of a tripartite agreement between the United States, Iran and the Netherlands dealing with the status of the Tribunal itself, the privileges and immunities of the arbitrators and staff, the status of the Agents of the two Governments and the relation of the Dutch legal system to the arbitrations conducted before the Tribunal.

As for the Dutch, "[i]t was assumed in the proposals which the Netherlands made in connection with the preparations for the reception of the Tribunal in the Netherlands that the Tribunal would operate as an arbitral body in hearing civil disputes and that Dutch law on Arbitration would therefore apply." ${ }^{178}$ As the work of the Tribunal began to pick up pace, the cooperation between Iran and the United States required to conclude the agreement dissipated and the negotiations stalled. The Iranian Agent, in the

\footnotetext{
${ }^{175}$ St'. e.g., Retised UNCITRAL Rules Released for Comment by Tribunal, I.A.L.R., Feb. 19, 1982, at 4,232 .

176 Article 1(3) of the Declaration, supra note 1, provides: "The Claims Settlement Declaration constitutes an Agreement in writing by Iran and the United States, on their own behalfs and on behalf of their nationals submitting to arbitration within the framework of the Algiers Declarations and in accordance with the Tribunal Rules." On the significance of this provision, see text at note 182 infra.

${ }^{177}$ Thus, the Tribunal decided on May 3, 1982, to register its awards in accordance with Article 639(1) of the Dutch Code of Civil Procedure, later superseded by the 1986 Netherlands Arbitration Act with Article 1058 of the Dutch Code of Civil Procedure. See Manual of the Registry of the Iran-United States Claims Tribunal. The former article of the Dutch Code called for deposit within 8 days at the Registrar of the district where the award was made. The latter calls for deposit "without delay" at the same location. On the new Dutch arbitration law, see generally van den Berg, The Netherlands, 12 Y.B. CoM. ARB. 3 (1987); and Tebbens, $A$ Fachlyf for Dutch Arbitration Law, 34 NETH. INT'L L. REv. 141 (1987). See also Sanders, A New Late for the Netherlands, 4 PACE L. REV. 581 (1984).

${ }^{17 \times}$ Explanatory Note of the Ministerie van Buitenlandse Zaken (Foreign Ministry) to a Proposed Bill on "Applicability of Dutch law to the awards of the Tribunal sitting in The Hague to hear claims between Iran and the United States" (July 12, 1983) (unofficial translation by Foreign Ministry).
} 
spring of 1982, for example, reportedly stated in regard to the legal personality of the Tribunal that "granting an independent legal status to the Tribunal is neither required nor warranted." 179

Owing to the parties' failure to conclude the tripartite agreement, the Dutch Government took a unilateral and less formal approach to those issues the agreement would have resolved. The arbitrators and SecretaryGeneral of the Tribunal were granted the privileges and immunities of a person of ambassadorial rank. ${ }^{180}$ Likewise, the Netherlands Government granted the Tribunal the usual immunities of international organizations, a grant cited by the District Court of The Hague in its dismissal of a former Tribunal employee's claim for wrongful discharge. ${ }^{181}$ In regard to the arbitrations before the Tribunal involving claims of nationals, the Dutch Foreign Ministry began a slow process of drafting legislation that would formalize and clarify the applicability of the Dutch arbitration law. The Foreign Ministry modeled this legislation on the draft tripartite agreement.

The Iranian challenge of Tribunal awards and the proposed Dutch legislation. The circumstances surrounding the introduction of the proposed Dutch legislation strongly suggest that Iran withdrew its support from the tripartite agreement for reasons other than opposition to the provisions relating to the applicability of Dutch arbitration law. Indeed, on April 8, 1983, Iran invoked Dutch law by requesting that the District Court of The Hague set aside or declare null and void two Tribunal awards. ${ }^{182}$ Iran filed other such challenges and by December 2, 1983, had a total of ten challenges pending in Dutch courts. ${ }^{183}$ Thus, it appears that until at least the end of 1983, Iran believed that the Dutch legal system governed the validity of Tribunal arbitrations.

This unanimous view of the Tribunal, the United States and Iran ended early in 1984. In July 1983, the Foreign Ministry submitted proposed legislation to the Dutch Parliament on the relation of the Dutch legal system to Tribunal awards. In part, a continuation of legislative efforts initiated within the framework of the stillborn tripartite agreement, the proposal was also a response to the two challenges Iran had filed in April 1983. The Second Chamber of the Dutch Parliament passed the law in February 1984 and sent it to the First Chamber for its concurrence. Iran thereupon reversed its position and adamantly opposed Dutch judicial review of the arbitral process. President Khamenei of Iran said at Friday prayers that the

${ }^{179}$ Letter of Arthur Rovine, Agent of the United States, to Christopher Pinto, SecretaryGeneral of the Tribunal (May 28, 1982).

${ }^{180}$ See Iran-United States Claims Tribunal, Annual Report for the Period End. ING 30 JUNE 1983, paras. 20-22, Anns. VI-IX.

${ }^{181}$ Spaans v. Iran-U.S. Claims Tribunal (Dist. Ct. The Hague, July 9, 1984), overruling decision of the Kantonrechter (County Ct. Judge) (The Hague, June 8, 1983), noted and reprinted in part in 18 NETH. Y.B. INT'L L. 357 (1987).

${ }_{182}$ See Iran Appeals Raygo Wagner, Rexnord Awards to Dutch Courl, I.A.L.R., Apr. 15, 1983, at 6,330. The two awards involved were Raygo Wagner Equipment and Star Line Iran, AWD 20-17-3 (Mangård, Mosk \& Sani (RS), arbs., Dec. 15, 1982), 1 IRAN-U.S. C.T.R. 411 (198182); and Rexnord and Islamic Republic of Iran, supra note 137.

${ }^{183}$ For a summary of these challenges, see Lake \& Dana, supra note 15 , at 759-65. 
United States had pressured the Dutch Government into preparing legislation that would prejudice Iran before the Tribunal. ${ }^{184}$ The Agent of Iran and one of the Iranian arbitrators appeared before the First Chamber to argue against passage of the law. Shortly thereafter, Iran withdrew all ten of its challenges before the Dutch courts so as to remove the motivation for the legislation. The Dutch Government, thereupon, without prejudice to its ability to renew the question if needed, ceased consideration of the legislation.

A letter from M. Eshragh, the Agent of Iran, protesting the proposed legislation after its passage by the Second Chamber suggests two reasons for the change in Iran's position. ${ }^{185}$ First, Iran had come to realize that its previous position would be inconsistent with the then-pending and, for Iran, politically sensitive dual nationality proceedings, in which Iran was arguing that the arbitrations were based on diplomatic protection. Second, by clarifying and limiting somewhat the grounds for setting aside an award, the proposed legislation lessened the value to Iran of subordinating the arbitrations to the Dutch legal system because Iran probably realized that its challenges would not be sustained. Simultaneously, this whole series of events likely made Iran increasingly aware that a corollary of its right to challenge awards in Dutch courts was the right of U.S. claimants to enforce them elsewhere, possibly under the New York Convention. Finally, to the degree that the challenges were primarily an Iranian strategy to persuade the Algerian Government, as escrow agent for the Security Account, to withhold payment on awards, that effort had already failed. ${ }^{186}$

Iran's action to enforce the Gould award in the United States. Iran's position in favor of characterizing the Tribunal's work as diplomatic protection and against passage of the proposed legislation remained constant from the spring of 1984 until June 1987, when Iran attempted to enforce an award of the Tribunal in the United States under the New York Convention on the ground that the award had Dutch nationality. On June 29, 1984, Chamber Two of the Tribunal had rendered an award in favor of the Ministry of Defence of the Islamic Republic of Iran and against Gould Marketing, the U.S. party, for $\$ 3,640,247.13 .{ }^{187}$ Gould failed to pay the debt. On June 9 , 1987, 20 days shy of the 3-year limit under the New York Convention (9 U.S.C. $\$ 207$ (1988)), Iran petitioned the U.S. District Court for the Central District of California to enforce the award. ${ }^{188}$ Judge Gadbois's order hold-

\footnotetext{
IN' St MEALEY'S, Apr. 6, 1984, at 299-300.

't's Reprinted in 5 IRAN-U.S. C.T.R. 405 (1984 I).

i*t. Normally, the Algerian Government as escrow agent would order the payment of monies fron the Security Account upon receipt of a notification of award from the President of the Tribunal. When challenging awards in 1983, Iran also persuaded Algeria for a time that it should withhold payments on those awards until the challenges to their validity were decided. By November 1983, however, the United States had convinced Algeria that Algeria's function was nondiscretionary and all payment orders were made. See I.A.L.R., Nov. 18, 1983, at 7,472.

${ }^{\text {ix7 }}$ Gould Marketing and Ministry of Defence of Islamic Republic of Iran, AWD 136-49/ 50-2 (Riphagen, Aldrich \& Shafeiei (CO/DO), arbs., June 29, 1984), 6 IRAN-U.S. C.T.R. 272 (1984 II).

${ }^{1 \times x}$ I.A.L.R., July 10,1987 , at 14,407 .
} 
ing that U.S. district courts have subject matter jurisdiction over actions to enforce Tribunal awards under the New York Convention, as codified in U.S. law, was recently affirmed by the U.S. Court of Appeals for the Ninth Circuit. ${ }^{189}$ Iran's position, however, has not quite come full circle. It still maintains before the Tribunal that the United States espouses the claims of its nationals on the basis of diplomatic protection. ${ }^{190}$

In conclusion, the Accords established a clear presumption that the legal system of the Netherlands would govern the Tribunal's arbitral process. The state parties and the Tribunal confirmed this desire by not modifying the UNCITRAL Rules in this regard. Finally, the subsequent practice and statements of the United States and Iran (although the latter's practice has been somewhat inconsistent) confirm their desire that the Tribunal's arbitrations be subject to review under the Dutch legal system.

\section{Ability and Willingness of the Netherlands to Accommodate the Parties' Desire}

Even if the United States and Iran intended that the Dutch legal system govern these arbitrations, the Dutch may not necessarily have been willing or able to accept this role.

As to willingness: The United States and Iran in essence requested that the Netherlands supervise the dispute settlement process they established. If the state parties had sought to place this supervisory role on the Dutch executive branch, the international consent of the Dutch Government would have been required. Whether two countries can avoid obtaining such consent by placing their disputes within the national arbitration scheme presents an issue of constitutional law regarding the respective roles of the executive and judicial branches of that country in foreign affairs. ${ }^{191}$ For example, if two countries sought to have the U.S. legal system govern the validity of a border arbitration between them, a strong constitutional argument could be made that the judiciary should abstain from assuming a role that could lead to substantial friction with at least one of the states involved and the concomitant embarrassment of the executive branch. ${ }^{192}$ The Netherlands, however, consistent with its long-time role as a mediator of international disputes, apparently did not hesitate to allow its judiciary to supervise the Iran-U.S. Claims Tribunal's proceedings concerning at least the claims of nationals. ${ }^{193}$ Instead, the issue has been quite formal: did Iran and the United States create an arbitral process that meets the threshold requirements of arbitration as defined in the Dutch Code of Civil Procedure? ${ }^{194}$ In particular, the question whether Article II(1) proceedings are arbitration

${ }^{189}$ Id., Apr. 29, 1988, at 15,654. $\quad{ }^{190}$ See supra note 132.

${ }^{191}$ Indeed, such direct entry into a national arbitration scheme would not be possible in the United Kingdom where $\S 9$ of the Sovereign Immunity Act provides that although a state is not immune from proceedings before UK courts related to an arbitration to which the state agreed, this denial of immunity "does not apply to any arbitration agreement between states."

${ }_{192} \mathrm{See}$, for example, the concerns expressed by the court in Occidental of Urnm al Qaywayn v. A Certain Cargo of Petroleum, 577 F.2d 1196, 1203-05 (5th Cir. 1978).

${ }^{193}$ See supra text at notes $174-81$.

${ }^{194}$ In at least one instance, a municipal court at the place of arbitration has held that the applicable municipal law did not govern an arbitration because the proceedings did not consti- 
within the meaning of the Dutch code raises the technical, yet significant, requirement that the agreement to arbitrate shall be in writing and signed by the parties. ${ }^{195}$ Van den Berg, referring to the New York Convention, states that the purpose of the written requirement "is to ensure that a party is aware that he is agreeing to arbitration." ${ }^{196}$ In this sense, the writing is the objective manifestation of the consent of the parties, the voluntary act that underlies the notion and legitimacy of arbitration.

There can be little doubt that Iran and the United States, the two state parties, knew they were agreeing to arbitration. Moreover, the conduct of Iran from the time of its challenges in the Dutch court indicates that Iran, like the United States, was aware that it had agreed to arbitration governed by the Dutch legal system. Thus, Iran could be regarded as being estopped from raising the issue of its written agreement. ${ }^{197}$ Hardenberg argues, however, that for claims of nationals before the Tribunal, there clearly is not an arbitration agreement between the litigants. ${ }^{198}$ For support, he cites the Explanatory Note of the Dutch Foreign Ministry accompanying the proposed bill: "Given the absence of voluntary prior contractual agreement between the parties concerned in each individual case and the international nature of the agreement between States underlying the arbitration, doubts may arise as to whether this is indeed arbitration within the meaning of Dutch law." 199 The issue is therefore whether not only the state parties, but also their nationals, can be said to have agreed to arbitration.

tute "arbitration" as that term was defined by municipal law and that there was therefore nothing to be governed. See SEEE v. Yugoslavia (Swiss Fed. Trib., Sept. 18, 1957), reprinted in 47 RCDIP 366 (1958). Doctrinally, the position that there is nothing to be governed could be equated with the setting aside of an award. Compare SEEE v. Yugoslavia (Hague Ct. App., Sept. 8. 1972), reprnted in French in 1974 REV. ARB. 313, and SEEE v. Yugoslavia (Hoge Raad, Nov. 7,1975 ), 1976 Nederlandse Jurisprudentie No. 774, reprinted in French in 1978 REV. ARB. 397. St alsa Delaume, SEEE *. Yugoslatia: Epitaph or Interlude?, 4 J. INT'L ARB. 25 (1987). Whether such a refusal to review an award should be viewed as the equivalent of setting aside the award or simply as abstention because of concerns with competence is a difficult question that turns upon the specific reason the court feels it cannot or should not examine the award.

${ }^{145}$ The provision of the Dutch Code of Civil Procedure referred to provides that the "arbitration agreement . . . must be made in writing and signed by the parties." Dutch Code of Civil Procedure, Art. 623(1) (unofficial translation prepared by the Asser Institute, 1980). The arbitration agreement is also significant because such a writing is essential to the enforceability of the award, given that the writing requirement is also set forth in the New York Convention, suprot note 25. In particular, Article IV of the New York Convention requires that to obtain recognition and enforcement, the party applying shall present the award and the arbitration agreement, such agreement, by Article II of the Convention, being in writing by the parties.

${ }^{14 t 5}$ A. J. VAN DEN BERG, supra note 59, at 171.

${ }^{117}$ To van den Berg, estoppel in the context of the New York Convention would reflect "a fundamental principle of good faith, which principle overrides the formalities required by Article II(2) of the New York Convention." Id. at 185.

${ }^{14 \times}$ Hardenberg, supra note 13 , at 338.

${ }^{1 \cdots}$ Sir note 178 supra. This problem may explain a less specific statement of a U.S. Department of State official some months after the signing of the Accords: "Upon examination of Dutch law, it became apparent that awards rendered pursuant to the Claims Settlement Agrcement would not meet certain procedural requirements for valid arbitral awards under the Dutch civil code." Feldman, supra note 172 , at 98. 
One answer is that each state party possesses the authority to agree to arbitration on behalf of its nationals. As van den Berg wrote in response to Hardenberg: "It is arguable that an arbitration agreement can be considered to be present if one regards Iran and the United States as also representing the interests of their subjects when bringing about the Claims Settlement Declaration." ${ }^{200}$ Indeed, this position is supported by Article 1(3) of the Tribunal's Rules, which provides: "The Claims Settlement Declaration constitutes an Agreement in writing by Iran and the United States, on their own behalfs and on behalf of their nationals submitting to arbitration within the framework of the Algiers Declarations and in accordance with the Tribunal Rules."201

Although the view of the state as agent is likely sufficient, for this Tribunal one can also find the direct agreement of the nationals to arbitrate. To do so, one must recognize that the Accords manifest a written agreement between Iran and the United States to participate in binding arbitrations of claims brought not only by the other, but also by nationals of the other, even though such nationals were not parties to the Accords. In this sense, the Accords embody a written offer by each state party to the nationals of the other state party to arbitrate certain claims. ${ }^{202}$ This offer could be accepted in writing by individual claimants by filing Statements of Claim prior to January 19, 1982. Indeed, each Statement of Claim included an element not normally required by the UNCITRAL Rules, "[a] demand that the dispute be referred to arbitration by the Tribunal."203 Although it is true that the Algiers Accords compelled U.S. claimants to abandon their proceedings in U.S. courts, the Accords did not compel them to file or defend claims before the Tribunal. As Mr. Justice Hobhouse observed in Dallal v. Bank Mellat:

It was Mr Dallal's voluntary act to commence the proceedings before the Hague tribunal. It is true that he may have had no other alternative under the law of the United States if he wished to pursue his rights as he saw them. But that does not make it any the less a voluntary act. ${ }^{204}$

\footnotetext{
${ }^{200}$ Van den Berg, supra note 14 , at 343 (emphasis in original).

201 This provision was added to Article 1 of the UNCITRAL Rules as a part of the Tribunal's modification of those Rules. See Tribunal Rules, supra note 143, 2 IRAN-U.S. C.T.R. at 408.

${ }^{202}$ Georges Delaume has argued that such a form of agreement would be sufficient for ICSID: "Consent may also result from the investor's acceptance of a unilateral offer from the Contracting State involved, when that State has already consented to ICSID arbitration in relevant provisions . . . of a bilateral treaty with the Contracting State of which the investor is a national." Delaume, ICSID Arbitration: Practical Considerations, 1 J. INT'L. ARB. 101, 104 (1984). Similarly, although the recent UNCITRAL Model Law on International Commercial Arbitration requires a written agreement to arbitrate, a writing exists if there is "an exchange of statements of claim and defense in which the existence of an agreement is alleged by onc party and not denied by another." UNCITRAL Model Law, supra note 49, Art. 7(2). See also Furnish, Commercial Arbitration Agreements and the Uniform Commercial Code, 67 CAL. L. REV. 317,347 (1979) ("The arbitration agreement should be made amenable to autonomous creation through the same means recognized for the creation of a sales agreement . . .").

${ }^{203}$ Tribunal Rules, supra note 143, Art. 18(1)(a), 2 IRAN-U.S. C.T.R. at 422.

${ }^{204}$ Mark Dallal v. Bank Mellat, [1986] 1 All E.R. 239, 254.
} 
A quick response might be that although Dallal's act could be said to be voluntary in that he was not coerced, is an act voluntary when there is no other choice? Yet, as Mr. Justice Hobhouse notes, what choice does any plaintiff have? "Most plaintiffs who commence proceedings are in a similar position. They have to commence proceedings before the appropriate municipal court or else be without legal remedy."205

In this connection, it must be recalled that the Tribunal possesses jurisdiction over the claims of nationals of one state party against the other state party, but not vice versa. ${ }^{206}$ The Tribunal is unlike a court in that the nationals of each state party may choose to be a plaintiff, but may not be forced to be a defendant. Thus, a written agreement to arbitrate lies in the acceptance by the national of one state party of the other state party's written offer in the Accords, through that national's choice to file a written demand for arbitration.

\section{The Legal Character of Arbitrations before the Tribunal}

The question of what legal system governs proceedings before the Tribunal is troublesome because, despite the apparent clarity of the state parties' intent, it does not fit neatly into the pigeonhole normally assigned to international arbitral tribunals created by states. At the beginning of this century, Iran and the United States probably would have intended that the claims of their nationals be espoused via diplomatic protection. They probably would have had no other choice. They certainly had other choices in 1981 .

Granting that at the time of the signing of the Algiers Accords the state parties perhaps had not fully developed their negotiating position on the legal system that would apply to the arbitral proceedings, the Accords nonetheless establish a presumption that those involving claims of nationals are governed by the Dutch legal system. Granting also that there was both indecision and confusion about this question for several months following the signing of the Accords, this initial uncertainty is far outweighed by the subsequent practice of both the United States and Iran. Finally, although Iran has opposed Dutch judicial review at times, the Accords clearly provide that the choice of Dutch review cannot be altered without the consent of both state parties or action of the Tribunal itself, requirements that have not been met.

To conclude that Iran and the United States agreed that the Dutch legal system should govern the arbitrations involving claims of nationals does not necessarily mean that the choice promotes the interests of the parties or the Tribunal. Lake and Dana argue that awards do not require nationality to be enforceable under the New York Convention (the chief benefit, in their

205 Id.

ziti Islamic Republic of Iran and United States (Jurisdiction Over Claims by a State Party Against Nationals of the Other State Party), Dec. I-A2-FT (Lagergren, Holtzmann, Kashani (D), Bellet, Aldrich, Shafeiei (D), Mangård, Enayat (D) \& Mosk, arbs., Jan. 26, 1982), 1 IR.IN-U.S. C.T.R. 101 (1981-82). 
view, of Dutch review), while the applicability of Dutch law might force claimants to defend against Iranian challenges in lengthy Dutch court proceedings. ${ }^{207}$ In addition, they argue that judicial recourse risks renewal of Iranian attempts to have the Algerian Escrow Agent withhold instructions for payment from the Security Account until such challenges are resolved. 208

Putting aside the fact that it is the intent of the parties and not considerations of policy that determines the lex arbitri, the interests of the Tribunal and of international dispute settlement arguably are advanced by Dutch review. The ability to challenge the award at the place of arbitration continues to be appropriate and valuable. Fairness suggests that the losing party should have a primary place in which to question the award immediately, rather than being forced to raise the issue whenever and wherever the winning party seeks enforcement or recognition. Most national laws require that challenges be raised within a limited period after the rendering of the award. This requirement provides a basis for estopping a dilatory objecting party. If there is merit to the challenge, the court may wish to question the arbitrators and to examine the records of the Tribunal. Far less disruption is engendered if such inquiries are made at the place of arbitration rather than at the place of enforcement. Moreover, by providing a mechanism for setting aside fundamentally unfair awards, the state parties bolster the legitimacy of the process and the Netherlands furthers its own interest in continuing to serve as a fair and impartial site for the peaceful legal resolution of disputes.

Last, there is no apparent reason for the conclusion that the Dutch legal system governs the arbitrations involving claims of nationals not to be equally applicable to the arbitrations involving official claims and interpretive disputes. The presumption that the Accords involve the Dutch legal system flows from the choice of the UNCITRAL Rules, a choice that does not distinguish among the various bases of jurisdiction. Nor should we necessarily jump to the conclusion that the state parties would have desired to distinguish the bases of the Tribunal's jurisdiction. In particular, the official claims are based on "contractual [not treaty] arrangements between them for the purchase and sale of goods and services." Most, if not all, official claims, although intergovernmental, involve commercial matters. ${ }^{209}$ Moreover, the enforceability concerns cited above are also applicable to the official claims. On the other hand, several U.S. and Tribunal officials expressed to me the belief that if the circumstance arose, the state parties would act to block the subjection of proceedings involving official claims and interpretive disputes to the Dutch legal system. A further important difference might be the willingness of the Netherlands to accept these other two categories of disputes for judicial review. The proposed Dutch legislation puts that willing-

\footnotetext{
${ }^{207}$ Lake \& Dana, supra note 15 , at 807. $\quad{ }^{208}$ Id. at 808-09.

${ }^{209}$ The qualification "most, if not all," is used in the text to reserve the potentially important question whether the sale of arms by a government, although contractual, is or is not a commercial matter.
} 
ness in some doubt, as it expressly applied only to the arbitrations involving claims of nationals. This single piece of evidence, however, is too slender a reed to bear the conclusion that the Netherlands will not accept the role proposed by the United States and Iran if an issue concerning an official claim or interpretive dispute arises.

\section{The Evolving STRUCTURE OF INTERNATIONAL DISPUTE RESOLUTION}

In 1914 and 1916, Mr. Mavrommatis obtained concessions from the Ottoman Empire to provide certain public services in Jerusalem and Jaffa. After the First World War, the British Government granted duplicate concessions to a different person. Predictably, a dispute ensued. The Government of Greece eventually espoused the claim of Mavrommatis, its national, against the British Government on the basis of diplomatic protection. Ultimately, the claim was addressed on the public international law level by the Permanent Court of International Justice. ${ }^{210}$

The conventional wisdom is that interstate arbitration, like that involving Mavrommatis, has declined in this century. Parry wrote that "the high noon of international arbitration occurred around the year 1900." 211 Yet further consideration of Mavrommatis's situation tells us that the evolution of international arbitration more generally in this century involves a process far more complex than a mere decline in use.

In the early 1920s, Mavrommatis had few, if any, other options for pursuing his claim. Today, in contrast, he would likely include, as a part of his concession, a clause providing for international commercial arbitration in, for example, Geneva under the UNCITRAL Rules of Arbitration or Paris at the International Chamber of Commerce. In contrast to settlement by the Permanent Court of International Justice, this proceeding would not require the cooperation of the other party and could result in an award enforceable and recognizable around much of the world under the New York Convention.

Many arbitrations at the turn of the century, like the Mavrommatis case, involved claims of individuals based on diplomatic protection. That is, many of the disputes were not truly between the two states named as parties.

\footnotetext{
"2" Sit Mavrommatis Palestine Concessions, 1924 PCIJ (ser. A) No. 2 (Judgment of Aug. 30). My use of the Matrommats case builds upon Professor Franck's use of the proceeding to illustrate the costs of approaching private disputes as international matters. T. FRANCK, THE STRUCTURE OF IMPARTIALITY 213-14 (1968). "What had been a quarrel between businessmen and an administrator became a dispute pitting Britain against Greece, kingdom against kingdorn, national pride against national pride . . . Id. at 214.

"1" Parry, Somk Considerations upon the Protection of Individuals in Intemational Law, 90 RECUEIL. DES COURS 653,660 (1956 II). Nor is this piece of wisdom without apparent statistical support. $\Lambda$ brief digest of all public international arbitral tribunals yields the following distribution of those tribunals over time: $1776-1800,7 ; 1801-1825,20 ; 1826-1850,17 ; 1851-1875,66$; $1876-1900,137 ; 1901-1925,133 ; 1926-1950,41$; and 1951-1970, 20. A. M. STUYT, SuRVEY OF INTERNATIONAL ARBITRATION 1794-1970 (1976). (Note that these numbers repreunt tribunals, not claims. Some tribunals heard only one claim; some after World War I heard 20,000 .)
} 
Today, depending upon the circumstances, similar claims likely would be handled through lump sum settlement or international commercial arbitration. Thus, the aggregate effect of the change in options described for Mavrommatis is that there quite plausibly has been a shift in dockets. Although further empirical study is necessary to establish the historical proposition, international commercial arbitration clearly has the capacity to take over the adjudication of many of the essentially private disputes previously addressed by the more politically contentious interstate mechanism of diplomatic protection.

The change is striking. In approximately half a century, an elaborate system for the resolution of international commercial disputes has evolved quietly and efficiently. When viewed against the history of international dispute resolution, this recent evolution is more accurately a revolution. Interstate arrangements, municipal court systems and private contractual dispute settlement systems reflect distinct doctrinal categories. In practice, however, they reflect different options for the resolution of clisputes. Different groups can control the shape of each process, and they naturally shape and develop the process they control so that it addresses the needs of the group. The processes, although conceptually distinct, do not operate in isolation. Each evolves in response to the needs of the community controlling it and each of the other mechanisms may be affected by such changes. This is not to say that interstate arbitration, international commercial arbitration and municipal legal orders collectively are developing in accordance with some master plan or that they are not duplicating one another or not competing with one another. ${ }^{212}$ It is to say that the community of commercial actors operating internationally demanded a more efficient and enforceable system than traditional interstate arbitration. That it was primarily businessmen and private lawyers who built the international commercial

\footnotetext{
${ }^{212}$ One cannot say that there was conscious interaction between the processes of private and public international arbitration during most of this century. Nor can the two processes be said to have been studied comparatively in detail. (A notable early exception in the form of a brief monograph is F. Kellor \& M. DOMkE, Arbitration in INTERNational Controversy (1944).) Yet this should not be surprising. The joint existence of the two processes is a rather recent phenomenon, international commercial arbitration generally only having flourished since World War II. Sociologically, even today the two processes remain distinct, in part because, except for certain arbitrators, two very different groups deal with public and private international arbitration. (See supra note 28.) For a recent valuable interactive discussion of the two processes, see Vagts, Dispute-Resolution Mechanisms in International Business, 203 RECUEIL DES Cours 9, 71-88 (1987 III).

In a practical sense, the lack of attention presented few problems until the Iran-United States Claims Tribunal. The Tribunal brought under one roof both public and private international arbitration and the two groups associated with such proceedings. Government officials found themselves pondering the significance of the nationality of the award3, while private counsel contemplated the effect of declarations of nullity. On procedural matters one can find many instances of citation by the Tribunal of public international arbitral awards as precedent for procedural decisions it took in what it apparently regarded as a private international arbitral matter. In this sense, the Tribunal is serving as a vehicle whereby the groups dealing with public and private international arbitration are getting to know each other and each other's work.
} 
arbitration system from the bottom up, rather than states from the top down, makes it no less of a revolution and all the more striking.

Many forces fueled the emergence of international commercial arbitration. There was an increased need for dispute resolution as the world saw a tremendous expansion of international commerce. Business executives sought security in an environment where previous assurances were no longer thought to suffice. The inability of public international law to adapt quickly to these changing circumstances and satisfy these concerns spurred a search for alternatives. Among other things, the strong tendency to limit standing in interstate arbitration to states did little to satisfy the concerns of the growing number of private international actors. ${ }^{213}$

Thus, as the system that was intended to provide international order proved inadequate and, as important, unresponsive to private international actors, pressures grew within municipal legal systems for more liberal assertions of jurisdiction on the basis of contacts, and for the revision of laws pertaining to the immunity of states from jurisdiction and enforcement. Likewise, efforts were directed at developing international commercial arbitration as an alternative. The success of both international commercial arbitration and transnational litigation was facilitated by the internationalizing of finance and markets, and the consequent dispersal of assets around the world. ${ }^{214}$

The effort to develop a private international arbitral system involved forming (1) a reliable means to enforce both arbitration agreements and arbitral awards, and (2) a fair and predictable arbitration process. From the first, enforcement was seen as the key to a meaningful process. Private international actors in conjunction with their governments used the basic tool of public international law, the treaty, to establish this enforcement regime. ${ }^{25}$ In essence, the New York Convention places the coercive power of many of the world's courts at the disposal of private parties so that they may remove actions to, and ultimately implement the decisions of, their private legal systems.

\footnotetext{
21 'The institution of diplomatic protection must always have been somewhat suspect in the mind of the national involved. First, the national had to seek the consent of his or her governmint to raise the claim; second, the claim on the public plane could become politicized and thus subject to unknown influences; and third, the enforceability of any resulting award was uncertain. Moreover, the enforceability of awards based on diplomatic protection, uncertain as that was, became yet more uncertain after World War II, as the threat of using armed force (which, it has been argued, stood behind the claims commissions at the turn of the century) was, at least in theory, prohibited. See Shihata, Touards a Greater Depoliticization of Investment Disputes: The Rules of ICSID ald MIGA, I FOREIGN INVESTMENT L. REV. 1 (1986).

"l "Sir", a,g., Buxbaum, supra note 19. See also C. LiPSON, STANDing GuARD: Protecting Foreign Capitil in the Nineteenth and Twentieth Centuries (1985).

: 15 The private, rather than governmental, hand in the design of the public law aspects of the private international arbitration system arguably is exemplified also by the recent rapid transformation of municipal arbitration statutes, which reduce court interference to a minimum while retaining the imprimatur of the state's endorsement of the validity of the process. See supra note 64.
} 
The second dimension, development of a fair and predictable arbitral process, has been a more arduous task. States modernized their municipal laws, and regional efforts at harmonizing such laws were made. The legal profession engaged in massive educational programs and comparative studies of the private arbitration laws of all states. Ultimately, UNCITRAL has sought on a global basis to harmonize the internal and external dimensions of municipally governed arbitration through two ambitious efforts: the 1976 UNCITRAL Rules of Arbitral Procedure and the 1985 UNCITRAL Model Law on International Commercial Arbitration.

If the "top-down" mechanisms of public international arbitration inadequately responded to the needs of the private international community in the first two-thirds of this century, the Iran-United States Claims Tribunal signifies how quickly states have accepted municipally enforceable arbitration in the last third. ICSID can also be viewed in this manner. Like the Tribunal, ICSID originated in a treaty. Unlike the Tribunal, the validity of ICSID proceedings is expressly governed solely by the international regime established by its constituent instrument. Municipal courts of contracting states are expressly barred from reviewing or interfering in ICSID proceedings. ${ }^{216}$ ICSID, however, like the international commercial arbitration system, responds to the demand for more effective dispute resolution. It does so by borrowing heavily from the structures of international commercial arbitration. ICSID replaces the traditional public approach of diplomatic protection with a regime permitting private parties to participate directly in arbitrations with states. Likewise, the traditional limitations on enforcement of awards are replaced by a direct private right of enforcement for both state and private parties in the municipal courts of any contracting state.

ICSID and the Tribunal are not isolated examples. The current arbitration between the United States and the Soviet Union over the U.S. Embassy under construction in Moscow rests upon an interlocking net of arbitration clauses, which, by adopting the UNCITRAL Rules of Arbitral Procedure and designating Stockholm as the place of arbitration, apparently establish a process within the supervisory jurisdiction of Sweden and the ambit of the New York Convention. The recent Treaty on Fisheries between the Governments of Certain Pacific Island States and the United States provides that a certain number of fishing licenses will be issued to U.S. nationals each year. Annex II to the Treaty carefully details the grounds upon which a license can be denied in any particular case. Any dispute between the state parties relating to or arising out of the Treaty is subject to arbitration under the UNCITRAL Rules. ${ }^{217}$

The evolution from diplomatic protection to international commercial arbitration and to institutions such as the Tribunal and ICSID is in the international community's interest. The trend away from classic interstate arbitration is desirable politically because it reduces the significance of the

216 See generally Delaume, supra note 38.

${ }^{217}$ Art. 6.2, Treaty on Fisheries, Apr. 2, 1987, 26 ILM 1048, 1062 (1987). 
state as a world actor in areas where the sensitivities of the state need not be implicated. Moreover, the flexibility of private arrangements is coupled with the assurance of harmonized municipal enforcement standards. The resulting low-level national permeation supports the rule of law by its implicit reliance on the existence of independent national judiciaries. ${ }^{218}$

The trend is desirable economically as well. Because the most directly affected parties are involved, both the costs and potential rewards of the process fall to the persons or entities that control it. This cost-benefit allocation promotes efficient decisions about the design and subsequent conduct of arbitral proceedings. Moreover, it is fair to say that the transfer of commercial disputes to the more enforceable process of private international arbitration not only prevents essentially private disputes from rising to the level of international conflict, but also furthers international investment and economic cooperation.

Finally, the transfer of certain disputes to private arbitration does not leave interstate arbitration bereft of content. Rather, it brings more clearly into focus what have always been the central tasks (and the major limitations) of interstate arbitration. Interstate arbitration has worked very well for resolving boundary disputes but not as well for disputes involving central interests of the state, such as the use of force. Although the volume of interstate arbitration may be less than it was at the turn of the century, international resolution of disputes generally is likely at an all-time high. Since these new mechanisms now address disputes that previously were elevated to the level of interstate arbitration by diplomatic protection, it would not be surprising to learn that true interstate arbitration in fact has remained relatively constant. Understanding this evolution helps strip away the false belief that somehow international arbitration accomplished much more in the past.

Understanding the evolution also lays bare what yet needs to be done and suggests directions for doing so. The development of alternative systems for international commercial disputes is in many respects far along, but the broad area of torts, in particular those involving the environment and human rights, appears to be at quite a different stage, dependent at present on transnational litigation (perhaps facilitated by treaty) or interstate factfinding commissions. In this connection, it should be borne in mind that the foundation of the success of international commercial arbitration, the New York Convention, is not strictly limited to commercial matters.

\footnotetext{
${ }_{21 \times}$ Arbitration awards may be brought directly before the courts of 82 countries under the New York Convention. UNCITRAL, Status of Conventions, UN Doc. A/CN.9/325 (May 17, 1989). Moreover, although one cynically might speculate that a local judge in some instances would feel constrained to contact his or her foreign ministry for "guidance," in time judges likely will fill the roles given. On the other hand, recognizing once again the evolutionary interplay of the various mechanisms, a counterbalancing consequence of globally elevating the international role of national judiciaries may be that as they are called upon to address more disputes with an international flavor, the more likely it will be that judicial doctrines will arise to assure deference to, and thereby enable courts to avoid embarrassment of, the executive.
} 


\section{CONCLUSION}

The arbitral proceedings before the Iran-United States Claims Tribunal involving claims of nationals are governed by the legal system of the Netherlands. This conclusion does not sit easily with the prevailing tendency to think that the proceedings of a tribunal formed by treaty to resolve a crisis between two countries are an interstate process not subject to interference by municipal legal orders. The tension between this conclusion and intuition is all the more striking, as the support for the former is extensive, if not overwhelming. The prevailing tendency nonetheless persists because it rests upon a categorical distinction between public and private international dispute resolution that in the past reflected practice quite faithfully. This distinction, however, no longer adequately describes the variations in international dispute resolution. The inadequacy of the distinction is problematic particularly for the interpreters of treaties because it may lead them unconsciously to force the innovative features of a treaty into the pigeonholes of the past. Thus, unconscious reliance upon this distinction should be replaced with a case-by-case examination of the mechanism the parties intended to create. Where this is done, innovation through treaty is protected, and a means for the development of international organization preserved.

The desire to innovate is driven by the perception that existing mechanisms do not fulfill the needs of the parties. To the parties, the various mechanisms are not separate doctrines but, rather, alternatives that should be measured against their needs. In this way, the parties' needs fuel the evolution of these mechanisms. Two particularly important dimensions to international dispute resolution in which innovation has occurred are the means of reviewing the validity of the result and the means of gaining enforcement of the result. The emergence of specific machinery such as the Tribunal and ICSID, and the increasing incidence of transnational litigation involving states and international commercial arbitration with state parties -all concurrent with an arguably decreasing need to rely on diplomatic protection-indicate that the various private, state and interstate mechanisms for the resolution of international disputes should not be viewed as operating in isolation, but as competing with, and evolving in response to, one another. To be sure, this evolving system is not the result of a master plan; rather, it is the Darwinian consequence of numerous separate demands. A continuing task of scholarship is to inform the soundness of such demands, to make them more coherent and, consequently, to help guide the evolving structure of international dispute resolution. 